International Association for the Psychology of Language Learning (IAPLL)

Journal for the Psychology of Language Learning

ISSN: 2642-7001. http://www.iapll.com/journal

Volume 2, June 2020, pp. 26-56

\title{
The Foreign Language Classroom Anxiety Scale and Academic Achievement: An Overview of the Prevailing Literature and a Meta-Analysis
}

\author{
Elouise Botes, University of Luxembourg, Esch-sur-Alzette, Luxembourg \\ Jean-Marc Dewaele, Birkbeck, University of London, London, UK. \\ Samuel Greiff, University of Luxembourg, Esch-sur-Alzette, Luxembourg
}

\begin{abstract}
Foreign language learners experience a unique type of anxiety during the language learning process: Foreign Language Classroom Anxiety (FLCA). This situation-specific anxiety is frequently examined alongside academic achievement in foreign language courses. The present meta-analysis examined the relationship between FLCA measured through the Foreign Language Classroom Anxiety Scale (FLCAS) and five forms of academic achievement: general academic achievement and four competency-specific outcome scores (reading-, writing-, listening-, and speaking academic achievement). A total of $k=99$ effect sizes were analysed with an overall sample size of $N=14128$ in a random-effects model with Pearson correlation coefficients. A moderate negative correlation was found between FLCA and all categories of academic achievement (e.g., general academic achievement: $r=-.39 ; k=59 ; N=12585$ ). The results of this meta-analysis confirm the negative association between FLCA and academic achievement in foreign language courses.
\end{abstract}

Keywords: foreign language classroom anxiety, language learning anxiety, academic achievement, individual differences in language learning

Research on affective variables in the language learning context has been a consistently popular topic in applied linguistics over the past four decades (see Dörnyei \& Ryan, 2015; Gardner \& MacIntyre, 1993; Gkonou, Daubney \& Dewaele, 2017). One variable that has unfailingly garnered attention is that of foreign language classroom anxiety (FLCA), which has been defined as a "distinct complex of self-perceptions, beliefs, feelings and behaviours related 
to classroom language learning arising from a uniqueness of the language learning process" (Horwitz, Horwitz, \& Cope, 1986, p. 128).

FLCA is thus seen as a unique form of state anxiety that learners experience when they participate in learning and/or using a language (Horwitz, 2017), where the language learner is limited in their communicative ability in the language being learned (Horwitz, 2001; Horwitz, Horwitz, \& Cope, 1986). As the construct of FLCA is intrinsically tied to classroom learning, the relationship between FLCA and academic achievement is an oft-researched topic (Teimouri, Goetze, \& Plonsky, 2019). Research findings on this relationship between FLCA and academic achievement have been somewhat consistent - with Horwitz (2001) attributing this relative consistency to the uniform measure used to conceptualise FLCA. Indeed, before the introduction of the Foreign Language Classroom Anxiety Scale (FLCAS) in 1986, cross-comparisons of research on anxiety and its effect in the foreign language classroom was nearly impossible due to the divergent measures and definitions used - a period labelled the "Confounded Approach" by MacIntyre (2017). The publication of the FLCAS heralded of the start of the "Specialised Approach" where the use of the same instrument allowed comparability across studies (MacIntyre, 2017). Horwitz (2001) noted that consistent moderate negative correlations were found between FLCA and academic achievement. This may be a prevalent trend, however large negative correlations (Vo, Samoilova, \& Wilang, 2017), non-significant results (Alidoost, Mirchenari, \& Mehr, 2013), and positive correlations (Jee, 2014) have also been reported in recent years. In addition, even though a uniform measure of FLCA has been used across the majority of research in the field, inconsistency still occurs in the use of achievement measures. General academic achievement measures popularly used in the literature include grade point average scores (Aida, 1994) and test or exam scores (Dordinejad \& Ahmadabad, 2014). In addition, several studies use achievement measures pertaining to a specific competence in language learning, such as reading (Jee, 2016), writing (Abu-Rabia, 2004; Khodadady \& Khajavy, 2013), listening (Elkhafaifi, 2005; Legac, 2007), and speaking (Phillips, 1992; Satar \& Özdener, 2008).

A meta-analysis assesses the strength of the evidence in regards to the relationship between two variables and identifies a common effect across all studies. Thus, in order to fully investigate the strength of the evidence of a moderate negative relationship between FLCA and academic achievement, a meta-analysis on the topic will be conducted in this paper. In addition, 
in order to provide clarity on the achievement measures used, analyses will distinguish between each achievement measure and its subsequent composite effect size with FLCA.

\section{Literature Review}

FLCA can be seen as a distinct form of anxiety in the language learning process that may affect the outcome of language learning itself, as the "propensity to reach one's full potential as a language learner is partially determined by affective variables such as anxiety" (MacIntyre, 1995a, p. 96). FLCA refers to the specific construct designed and developed by Horwitz et al. (1986) and measured through the FLCAS, although the construct has also been referred to throughout the literature by the shortened "foreign language anxiety" or just "language anxiety". Throughout this study, these terms will be used interchangeably although still referring to the specific conceptualisation of the construct as determined by Horwitz et al. (1986).

FLCA has been dubbed a situation-specific anxiety and can be discriminated from trait or other state forms of anxiety. Trait anxiety has been compared to a 'personality style' or a habitual anxiety, whereas state anxiety is a psychological and/or physiological reaction to a specific adverse situation and is momentary (Roos et al., 2015). FLCA in turn is both a habitual anxiety that occurs whenever the learner is confronted with language learning, yet momentary as it only pertains to specific instances. Indeed, in a series of studies, MacIntyre and Gardner (1991, 1989) distinguished general forms of anxiety from a language anxiety factor, commenting that "situation-specific constructs can be seen as trait anxiety measures limited to a given context" (Gardner \& MacIntyre, 1991, p. 90).

FLCA can additionally be likened to other forms of situation-specific anxieties, such as social anxiety, communicative apprehension, fear of negative evaluation and test anxiety. Indeed, MacIntyre and Gardner (1989) argue that language anxiety may be seen as a form of social anxiety as it specifically focuses on socialising in the language being learned. In addition, Horwitz et al. (1986) further describe communication apprehension, test anxiety, and fear of negative evaluation as "useful conceptual building blocks" (p. 128) for the development of FLCA. Horwitz (2017) warns that reducing FLCA to these three building blocks is a misreading of the original paper and a "false premise" (p. 38). Indeed, "the emotions evoked by Language Anxiety go much deeper than a simple combination of anxieties" (p. 41). The main cause is the 
distress people experience at being unable "to be themselves and to connect authentically with other people through the limitation of the new language" (p. 41).

\section{Measurement of FLCA}

FLCA is measured by the 33-item, 5-point Likert scale questionnaire introduced by Horwitz et al. (1986). Since its induction in 1986, the scale has gained traction and remains extremely popular with peer-reviewed research published regularly utilising it. The FLCAS has been adapted or shortened in several studies (see Dewaele \& MacIntyre, 2014; Liu \& Huang, 2011) and translated into numerous languages, including Hungarian (Tóth, 2008), Persian (Alidoost et al., 2013), Arabic (Dewaele \& Al-Saraj, 2015) and Thai (Tanielian, 2014). The scale measures the conceptualisation of language anxiety specific to FLCA, with 20 of the items focusing on speaking and listening in the target language in particular (Rodríguez \& Abreu, 2003). The items of the FLCAS are not without criticism, as Sparks and Ganschow (2007) noted that, "items seem to be tapping students' perceptions and attitudes about language as well as their feelings about anxiety" (p. 261).

The psychometric evidence regarding the reliability and validity of the FLCAS point to the validity of the measure - although not without flaw. Horwitz et al. (1986) reported an internal consistency of $\alpha=.93$, with numerous studies also reporting high internal consistencies of $\alpha>$ 90 (Aida, 1994; Elkhafaifi, 2005; Gocer, 2014). In addition, Horwitz et al. (1986) reported an acceptable test-retest reliability $(r t t=.83)$. Tóth (2008) found evidence of response validity in think-aloud exercises of the Hungarian translation of the FLCAS. In addition, construct validity of the scale has received considerable research attention.

Differing factor structures underlying FLCA have been found in validation studies, with some shorter measures proposing a unidimensional structure (Dewaele \& MacIntyre, 2014) and other a multidimensional structure (Aida, 1994; Liu \& Jackson, 2008; Tóth, 2008). A possible reason for the variation in factor analysis results of the FLCAS is offered by Park and French (2013), who noted that the factor structure may differ across sample groups depending on proficiency levels and learning contexts. Another possible reason for the variation in factors may lie in the statistical methods used, as the factors garnered in exploratory factor analyses can be an artefact of the estimation and rotation methods used by the researchers (Field, 2005). 
Although the FLCAS is a highly popular measure, several other attempts have been made to define and design measures of language anxiety. Other measures include, but are not limited to: French Class Anxiety Scale (Gardner \& Smythe, 1975); French Use Anxiety Scale (Gardner et al., 1997); English Use Anxiety Scale (Clément, Gardner, \& Smythe, 1977); Second Language Speaking Anxiety Scale (Woodrow, 2006). In addition, several scales have been developed to measure specific language competencies' anxiety, such as the Foreign Language Listening Anxiety Scale (Elkhafaifi, 2005), Foreign Language Reading Anxiety Scale (Saito, Garza, \& Horwitz, 1999), and the Second Language Writing Anxiety Inventory (Cheng, 2004). These scales tend to measure a similarly broad construct of language anxiety, although they are often targeted towards a specific language learning domain or skill. In order to avoid confusion linked to different operationalisations of language anxiety and in the hope of deriving a definitive answer regarding effect size in the meta-analysis, a decision was made to only include studies utilising the FLCAS, whether in its original, shortened, or translated form. This limitation does not restrict the amount of studies included in the meta-analysis unduly, as the FLCAS has been widely accepted by the research community and as such is used in the majority of self-reported language anxiety studies.

\section{Academic achievement and FLCA}

Since the inception of FLCA, its relations to achievement in language learning has been under scrutiny (Horwitz, 1986). A research trend has emerged with the majority of studies reporting significant moderate negative correlations (Horwitz, 2000); however-as previously noted-deviations to the status quo still occur.

The debate regarding the directionality of the relationship between FLCA and academic achievement has been contentious. A strand of research led by the work of Sparks and Ganschow (see Sparks \& Ganschow, 1995, 2007; Sparks, Patton, Ganschow, \& Humbach, 2009) question the existence of FLCA as a construct independent of aptitude and contends that anxiety in language learning is the natural result of learning difficulties - particularly arising out of first language deficits. In a series of response papers (see Horwitz, 2000; MacIntyre, 1995a, 1995b) FLCA is defended, with the argument made that FLCA is an independent construct, distinct from aptitude, but which may influence or be influenced by the performance of the language learner. FLCA is therefore likened to other domain-specific forms of learning anxiety, such as 
mathematics anxiety (see Frenzel, Pekrun, \& Goetz, 2007; Zan, Brown, Evans, \& Hannula, 2006), which may have a detrimental effect on learning above and beyond the natural ability of the student (MacIntyre, 1995b). In addition, FLCA is argued to be a separate construct from first language learning deficits and subtle language learning disabilities, as several studies on the topic has found students who experience high levels of anxiety but are still successful language learners (MacIntyre, 1995a, 1995b). However, it should be noted that as this meta-analysis will utilise correlation coefficients in order to examine effect sizes across studies, no conclusion regarding the directionality can be made. Nevertheless, in this study, the construct of FLCA is seen as a variable distinct from achievement and aptitude, with the strength of the relationship between FLCA and academic achievement being under scrutiny.

Beyond the directionality debate, research in the field has also examined the relationship of FLCA and specific language competencies. Particular attention has been paid to the relationship of FLCA and oral classroom activities, which may indicate that listening to and speaking in the target foreign language may be specific anxiety-filled activities for foreign language learners. In particular, academic achievement in speaking activities and FLCA have been of interest (Phillips, 1992; Satar \& Özdener, 2008). Horwitz (personal communication) included an item on the paralysing effects of anxiety in the FLCAS after students told her about them "freezing up" during speaking activities. This association between FLCA and oral achievement may be attributable to the fact that anxiety has been found to interfere with the grammatical precision and interpretive ability of the language learner (Gardner \& MacIntyre, 1991). In addition, language anxiety not only interferes with speaking activities, but also affects the ability of the language learner to receive and decipher messages in listening activities (Kim, 2000). Indeed, several studies have found significant correlations between FLCA and listening academic achievement (Legac, 2007; Tóth, 2007). In particular, highly anxious students may have difficulties in discriminating sounds in listening activities (Horwitz, 1986), with Kim (2000) pointing out that the delivery speed of the activity and the level of vocabulary in particular being a source of contention for anxious students. In addition to speaking and listening, FLCA has also been found to be significantly related to reading- and writing academic achievement (Jee, 2016; Khodadady \& Khajavy, 2013). Saito et al. (1999) postulated that anxiety intervenes in the decoding and processing of text, with Sellers (2000) finding that 
students with higher levels of language anxiety recalling significantly fewer details from a reading text.

Thus, FLCA has been associated with general academic achievement in the target language, as well as academic achievement in the language competencies of speaking, listening, reading, and writing. In order to do justice to the prevalent research, within this meta-analysis academic achievement as an outcome measure will therefore be examined and coded into five categories (general-, reading-, writing-, listening-, and speaking academic achievement), with effect sizes calculated separately for each category of academic achievement.

It should be noted that a meta-analysis was recently conducted by Teimouri, Goetze, and Plonsky (2019) on second language anxiety and achievement, which found an overall effect size of $r=-.36(k=105 ; N=19933)$ between FLCA and academic achievement. Although the results of the previous meta-analysis could be compared and contrasted with the current study, it is important to note the differing methodology and data base in comparison between the two studies. Teimouri et al. (2019) included studies utilising numerous different scales measuring language anxiety, including the Foreign Language Reading Anxiety Scale (Saito et al., 1999), the French Class Anxiety Scale (Gardner, 1985), and the FLCAS. In contrast, the current metaanalysis specifically limits the inclusion criteria to studies utilising the FLCAS as designed and developed by Horwitz et al. (1986). This decision was made for two reasons: Firstly, the FLCAS is the only scale - to the authors' knowledge - to be validated across numerous contexts. More specifically, the FLCAS has been utilised in studies across different countries, differing educational contexts, age groups, and language groups. Secondly, the comparability between studies is ensured in that variables labelled as 'Foreign Language Classroom Anxiety' were indeed defined and captured in the same way in order to ensure an 'apples to apples' comparison. Measures such as the Foreign Language Reading Anxiety Scale were for example excluded, as the scope and definition of the language anxiety measured cannot be said to be synonymous with FLCA.

Thus, the results presented by Teimouri et al. (2019) can to a certain extent be compared and contrasted with the current study, whilst remaining cognizant of the narrower scope and stringent definitions utilised within the current article. Furthermore, additional insight may be provided by this current meta-analysis, as it may verify some findings made by Teimouri et al. 
Journal for the Psychology of Language Learning, Volume 2, June 2020, pp. 26-56. ISSN: 2642-7001.

http://www.iapll.com/journal

(2019) and raise yet more questions regarding the relationship between language anxiety and academic achievement.

\section{Possible moderators}

Research regarding moderators possibly influencing the direction or strength of the relationship between FLCA and academic achievement seems few and far in between. Several mean-level differences have been found in regards to FLCAS scores and/or academic achievement scores on the basis of demographic factors, cultural differences and learning contexts. However, it should be noted that mean-level differences across groups does not necessarily imply a moderator effect, which occurs when the relationship between two variables are entirely dependent on a third variable (Field, 2005).

Gender has been researched in FLCA and academic achievement studies, however results vary from study to study. Females have been found to have higher levels of FLCA in some research papers (Abu-Rabia, 2004; Dordinejad \& Ahmadabad, 2014; Park \& French, 2013), with others reporting no significant difference (Aida, 1994), and others still yet finding males to have higher levels of FLCA (Alidoost et al., 2013). However, no study could be found where the relationship between FLCA and academic achievement was moderated by gender in the sense that the size of the relation between FLCA and academic achievement differed between boys and girls. Thus, an exploratory stance will be taken within this meta-analysis with gender by examining the female proportion of participants as a possible moderator in the relationship between FLCA and academic achievement.

Some studies have found a significant relationship between FLCA and age, with older participants reporting higher levels of language anxiety in Onwuegbuzie et al. (1999) (Mean age $=22$, range 18-71). A non-linear negative relationship emerged in Dewaele and MacIntyre (2014) (Mean age $=24$, range 11-75) with pre-teens reporting lower FLCA than teenagers, after which FLCA went down before stabilising for participants in their thirties. No significant results were found in other research papers (Dewaele, Petrides, \& Furnham, 2008; MacIntyre, Baker, Clément, \& Donovan, 2002). However, Dewaele (2007) found additional complexity in the relationship between age and FLCA, depending on the conversation partner and number of languages known. Younger learners indicated less anxiety when communicating with strangers in their second and third languages, as compared to older language learners (Dewaele, 2007). 
Further complicating matters is the possible interaction effect between age and gender, with Samimy and Tabuse (1992) finding that gender plays a more important role in FLCA scores at a younger age. Although it should be noted that no studies could be found specifically examining the moderating effect of age in the relationship between FLCA and academic achievement, the mean differences reported by previous studies does provide justification as to examining the moderating effect of age on an exploratory basis. Therefore, as with gender, the average age of participants will thus be included as a possible moderator in this meta-analysis in an exploratory fashion.

The variability of language learning courses has been found to affect FLCA and academic achievement (Kim, 2009; Onwuegbuzie et al., 1999). More intensive language learning courses have been found to lower mean anxiety levels of students learning a foreign language (Baker \& MacIntyre, 2000; MacIntyre et al., 2003). Increased grade levels have also been associated with strengthening language anxiety as a predictor of achievement (Gardner, Smythe, Clément, \& Gliksman, 1976), however non-significant results have also been found in grade levels predicting the level of language anxiety in foreign language students (MacIntyre et al., 2002). In their meta-analysis on second language anxiety and academic achievement, Teimouri et al. (2019) found effect size differences between educational levels as well as study contexts. Research results in terms of language learning experiences are therefore highly contradictory and nearly impossible to compare from study to study - as descriptions of grade levels, intensity levels, and language learning experiences differ across educational settings, countries and cultures. As such, it was not possible to consider or code classroom context moderators beyond the educational setting of secondary school classes, university language courses and private language institute courses, which will be examined in an exploratory manner.

Due to the limitations of cross-comparisons and coding, only a handful of possible moderators could therefore be included in the meta-analysis of FLCA and academic achievement: average age of participants, the female proportion of the sample, and the type of language institution at which the language is being learned.

\section{Method}

\section{Search strategy}


Journal for the Psychology of Language Learning, Volume 2, June 2020, pp. 26-56. ISSN: 2642-7001.

http://www.iapll.com/journal

A comprehensive literature search was conducted in September 2018, using four online databases: PsychINFO, PsychARTICLES, ERIC and Google Scholar. An additional hand-search of three relevant peer-reviewed journals ${ }^{1}$ was carried out in January 2019. Articles published in English in peer-reviewed journals, conference proceedings, and dissertations submitted for doctoral degrees were examined. A two by four search grid was used in this study, with two keywords aimed at finding Foreign Language Classroom Anxiety (FLCA) measures ("Foreign Language Classroom Anxiety" OR "Language Anxiety") and four keywords aimed at finding a measure of the language learner's academic achievement in the language being learned (“Achievement" OR "Performance" OR "Grades" OR "Scores"). The search and review strategy of all literature followed the PRISMA guidelines to ensure transparent and consistent reporting of search methods and results (see Moher, Liberati, Tetzlaff, Altman, \& the PRISMA Group, 2009).

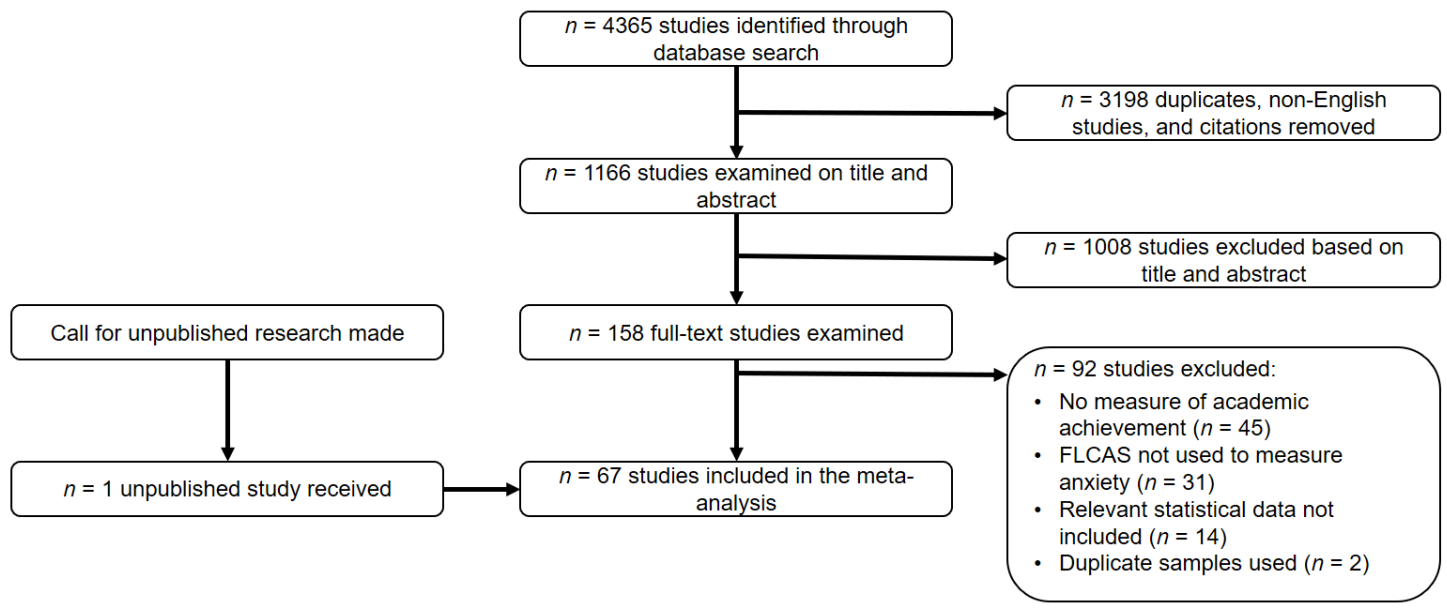

Figure 1. Selection Process for the Meta-analysis.

The database search and journal hand-search resulted in 4364 total results. The search functions in Google Scholar was utilised to exclude non-English results, citations, and duplicates. This resulted in 925 studies in Google Scholar being examined based on title and abstract. Along with the 925 studies, an additional 241 results were generated by PsychINFO,

\footnotetext{
${ }^{1}$ The Modern Language Journal, TESOL Quarterly, Language Learning.
} 
PsychARTICLES, ERIC, and the hand-search of journals. Thus, 1166 studies were examined on title and abstract, 1008 of which were excluded for being outside of the scope of the research question of this meta-analysis, for example merely referencing FLCA in a literature review on affective variables in applied linguistics. A total of 158 studies were examined in full-text as a result of the search, of which 66 were included in the meta-analysis. An additional call for unpublished research was made to limit the effect of the 'file-drawer problem', which refers to the bias in publication regarding non-significant results (Rosenberg, 2005). Unpublished data also increases the amount of grey literature in the dataset. Grey literature is an umbrella term for conference proceedings, unpublished dissertations, and unpublished data, and as such grey literature usually is not subjected to peer review. The inclusion of grey literature has been found to negate the effects of publication bias in meta-analyses (Conn, Valentine, Cooper, H, \& Rantz, 2003). The call for unpublished research resulted in one study being added to the meta-analysis to form a total of 67 . The selection process used for the meta-analysis is summarised in Figure 1. It should be noted that of the 67 studies included in the meta-analysis, 14 studies $(15 \%)$ can be considered 'grey literature'.

\section{Review Strategy}

Of the 67 studies generated by the literature search, a total of 99 effect sizes were included in the meta-analysis. The following inclusion criteria were applied:

1. Quantitative Data Requirements: Only quantitative studies were included in the metaanalysis. In addition, only studies that reported correlation coefficients between FLCA and academic achievement were included. In cases in which this information was not available, an attempt was made to reach out to authors if contact details were readily available. One response was garnered and added to the analysis.

2. Measurement of FLCA: Only studies utilising the FLCAS developed by Horwitz et al. (1986) were included. Translated or shortened versions of the FLCAS were also included, with specific deviations from the original 33-item questionnaire noted. Twenty-eight studies included used the original questionnaire, with 33 translated versions and 6 shortened versions utilised.

3. Measurement of academic achievement: General academic achievement was recorded either through grade point average scores or test/exam scores of the foreign language 
being learned. In addition, separate data entries for specific achievement measures on reading-, writing-, listening-, and speaking competency in the language being learned were made if available. These competencies were measured through tests, assignments and/or course grades. A summary of the academic achievement measures can be found in Figure 2.

4. Study Designs: No specific designs were excluded from the study. However certain guidelines were followed in regards to coding experiments and group-difference studies. In the experimental studies included in the meta-analysis, only preintervention data were recorded. In group-differences studies, the group total data was recorded if available, if not, separate groups were entered into the dataset and this was specifically noted.

5. Moderators: No exclusion criteria were used in terms of moderators.

\section{Coding Strategy}

The study recorded numerous publication, demographic and descriptive characteristics, as well as data relating to the effect sizes and possible moderator variables (Zessin et al., 2015). With regard to publication characteristics, the authors, year of publication, full title, and publication medium were recorded. The demographic characteristics recorded included sample size, gender distribution, average age, and country where the sample was gathered. Specific descriptive characteristics regarding language learning were also recorded, namely, language being learned, first language of sample, and whether the language course was undertaken through a school, university or private language institute. The measurement characteristics coded included extensive information on the specific version of the FLCAS that was used - whether the original or shortened version was utilised and if the measure was translated. Means, standard deviations, and internal reliability as measured by Cronbach's alpha $(\alpha)$ of the FLCAS were recorded for each study. Lastly, all possible measures of academic achievement were coded and recorded as outlined in Figure 2. Means, standard deviations and Pearson's correlations coefficient $(r)$ for each measure of achievement were recorded. 


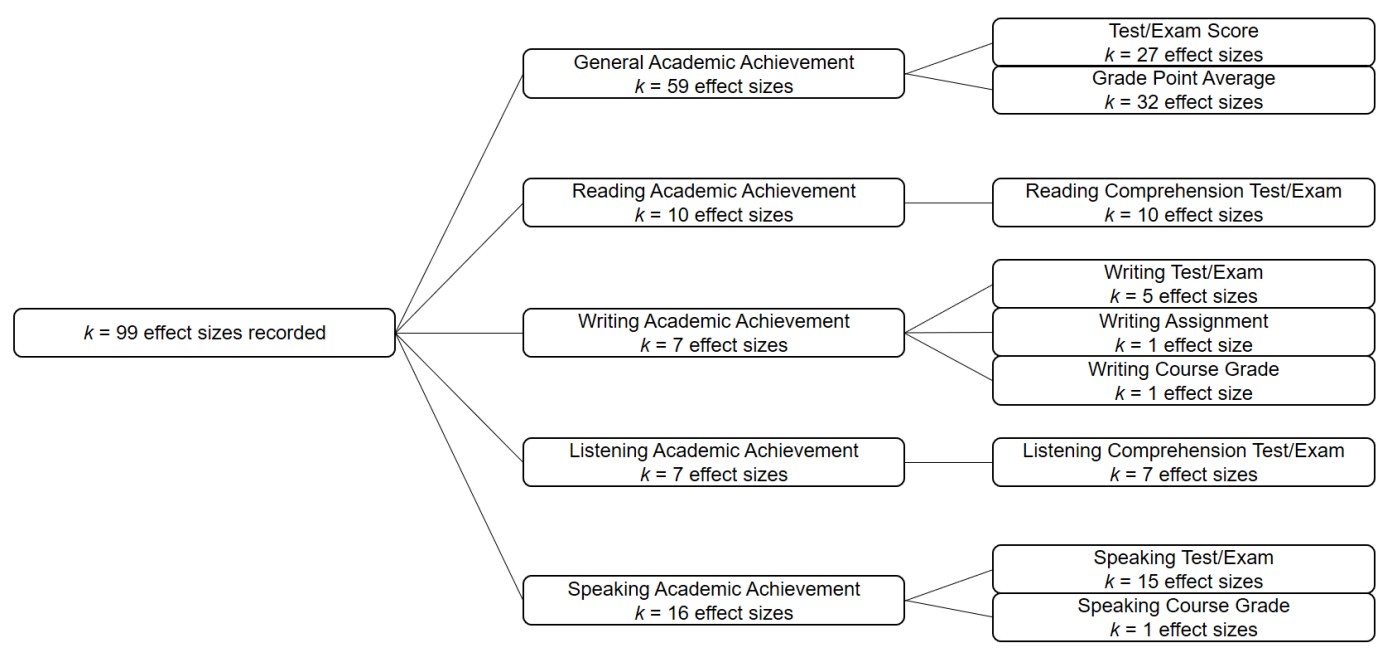

Figure 2. Effect Sizes of Academic Achievement.

Though an attempt was made to include and code several moderators in this metaanalysis, only three moderators were sufficiently represented in the included 67 studies to warrant further analyses. Firstly, the proportion of female participants in each study was calculated when a gender ratio of the sample was provided. Secondly, the average age of participants in each study was noted. If no average age was given, but the sample age range spanned two or three years (e.g. 16 - 17 years, see Satar \& Özdener, 2008), a mid-point in the age range was used. However, studies where the age ranges exceeded three years and no average age was provided were not included in the moderator analyses. Lastly, the institution type where the language learning took place was noted. The institution types where coded as School Language Course $(n=19)$, University Language Course $(n=43)$, or Private Language School Course $(n=5)$, and treated as a categorical variable. Due to the low number of private language school data entries, the category was not included in the final moderator analyses, and as such only School Language Course and University Language Course will be analysed as a possible categorical moderator.

An agreement rate (AR) was calculated in order to ensure the reliability of the coding process, with the proportion of exact matching codes and values calculated between two coders. Twenty of the 64 studies were coded by two coders, with the proportion of the number of observations agreed upon at an acceptable level of AR =90\% (Bayerl \& Paul, 2011). 


\section{Data-Analysis Strategy}

The hypothesised relationship between FLCA and academic achievement was examined via the 99 correlation coefficients collected from 67 studies. All analyses in the meta-analysis were conducted in R utilising the metafor package (Viechtbauer, 2010), with models being estimated using restricted maximum likelihood estimation. All correlation coefficients were converted into Fisher's $z$ scale in order to stabilise the variance of the results, with the summary of the Fischer's $z$ scale transformed to a summary correlation coefficient for each form of academic achievement that was measured (Hedges \& Olkin, 1985). A random effects model was used to conceptualise the 99 effect sizes as heterogeneity is assumed across studies. The Hedges and Olkin (1985) method was chosen as the Fisher $z$ scale transformation corrects for a skew in the sampling distribution of the correlation coefficients as the correlation coefficient value increases in the population (see Field, 2001). This skew is especially prevalent in studies with smaller samples, and as reading-, writing-, and listening academic achievement measures include only a small number of studies $(k<10)$.

The effects of the three moderator variables (average age, female proportion, and institution type) on the effect sizes were analysed utilising a random-effect meta-regression with a restricted maximum likelihood estimator in the Jamovi interface of $\mathrm{R}$ (Love et al., 2018). The effects of the moderator variables are analysed for each category of academic achievement, with the exception of listening academic achievement and average age as too few studies on listening academic achievement and FLCA reported average age for a moderator analysis to be viable.

As publication bias occurs with positive results being more likely to be published (Conn et al., 2003), the possibility of publication bias affecting the result of the meta-analysis was also investigated. A funnel plot was utilised to display the ratio of effect size to sample size in order to subjectively interpret the possibility of missing findings (Borenstein et al., 2011). In addition a trim-and-fill of the funnel plot was also provided in which an iterative procedure is used to recalculate the effect size if supposed publication biases were removed (Duval \& Tweedie, 2000). 


\section{Results}

\section{Descriptive Results}

From the 67 studies included in the meta-analysis between FLCAS and academic achievement, $k=99$ effect sizes were analysed. The publication dates included range from 1986 to 2018 , with the mean year of publication being $2009(S D=7.18)$. The total number of participants was $N=14,128$ (Mean $=210.87 ; S D=272.08)$. A total of 5,137 female participants and 5,464 male participants are included in the meta-analysis ${ }^{2}$. The majority of participants were learning English $(N=12,002)$, followed by Turkish $(N=589)$, French $(N=276)$, Arabic $(N=$ 233), and Spanish $(N=210)$. Other languages being learnt $(N=818)$ include German, Japanese, Korean, Mandarin-Chinese, and Persian. A large majority of participants received their language learning instruction via a university course $(N=9,063)$, followed by high/middle school classes $(N=4,019)$ and private language schools $(N=1,046)$.

\section{FLCA and general academic achievement}

The relationship between FLCA, as measured by the FLCAS, and general academic achievement was examined via the 59 effect sizes measuring either a grade point average or a general test/exam score of language learners. The correlation coefficients of each study were transformed to Fisher's $z$ and a random effects analysis conducted. The forest plot of all studies analysed can be found in the Supplementary Materials. FLCA and general academic achievement share a moderate negative correlation of $r=-.39(k=59 ; \mathrm{N}=12,858)$, with a $95 \%$ confidence interval of $r=-.45$ to $r=-.33$. The results are statistically significant $(Z=-12.4, p<$ $.001)$. Furthermore, the results indicated a significant amount of heterogeneity across studies $\left(Q(58)=399.22, p<.001 ; I^{2}=90.36\right)$, with a large amount of variance of the true effect sizes $\left(\tau^{2}\right.$ $=.045)$. It should be noted that the large amount of heterogeneity is most likely affected by the excess dispersion found in the effect sizes, as well as the number of effect sizes in the metaanalysis (Borenstein et al., 2011).

Therefore, it can be concluded that FLCA and general academic achievement have a moderately negative relationship and as such higher anxiety individuals are more likely to have a lower general achievement score in a language learning course.

\footnotetext{
223 studies included in the meta-analysis did not record the gender distribution of the respective samples. Thus,
} 3,527 participants do not have a gender classification in the meta-analysis dataset. 


\section{FLCA and reading academic achievement}

Reading academic achievement and FLCA showed a moderate negative correlation of $r=$ $-.342(k=10 ; N=995)$, with a $95 \%$ confidence interval of $r=-.405$ to $r=-.278$. The results are statistically significant $(Z=-10.6 ; p<.001)$. In addition, the results indicate that a small amount of heterogeneity exists across the 10 interaction effects $\left(Q(9)=11.34 ; p=.25 ; I^{2}=15.87\right)$, with almost no variance across studies $\left(\tau^{2}<.000\right)$. However, it should be noted that the relatively low $I^{2}$ value is influenced by the small number of studies included in the analysis. The purported lack of heterogeneity across the 10 effect sizes does provide further confidence in the proposed conclusion that language learners with higher levels of FLCA are more likely to also have lower levels of reading academic achievement.

\section{FLCA and writing academic achievement}

The meta-analysis of 7 effect sizes between FLCA and writing academic achievement results in a moderate negative correlation of $r=-.436(k=7 ; N=1098)$, with a $95 \%$ confidence interval of $r=-.569$ to $r=-.302$. The results are statistically significant $(Z=-6.41 ; p<.001)$. In addition, a moderate amount of heterogeneity is present in the studies included in this metaanalysis $\left(Q(6)=24.60 ; p<.001 ; I^{2}=75.41\right)$, with a small amount of variance across studies $\left(\tau^{2}=\right.$ .02). FLCA and writing academic achievement do therefore share a moderate negative correlation, however the test of heterogeneity does indicate some inconsistencies across effect sizes.

\section{FLCA and listening academic achievement}

The analyses of the 7 effect sizes between FLCA and listening academic achievement yielded a moderately large correlation coefficient of $r=-.525(k=7 ; N=986)$, with a 95\% confidence interval of $r=-.716$ to $r=-.333$. The results are statistically significant $(Z=-5.38 ; p$ $<.001)$. In addition, a large amount of heterogeneity is present in the studies included in this meta-analysis $\left(Q(6)=46.24 ; p<.001 ; I^{2}=87.86\right)$, with a large amount of variance across studies $\left(\tau^{2}=.06\right)$. The poor heterogeneity results are likely due to the dispersion of the data and the low precision of some data entries in the analysis (Borenstein et al., 2011). While some variation in 
true effect sizes across the studies is possible, the negative relationship between FLCA and listening academic achievement is clear.

\section{FLCA and speaking academic achievement}

FLCA and speaking academic achievement have a moderately small correlation coefficient of $r=-.257(k=16 ; N=1745)$, with a $95 \%$ confidence interval of $r=-.399$ to $r=$ .115. The results are statistically significant $(Z=-3.55 ; p<.001)$. Four studies found a positive correlation between FLCA and speaking academic achievement, whilst the majority of studies found a negative correlation. This dispersion of data is further evident in the large amount of heterogeneity that is present in the studies included in this meta-analysis $(Q(15)=121.16$; $p<$ $\left..001 ; I^{2}=86.86\right)$, with a large amount of variance across studies $\left(\tau^{2}=.07\right)$. The large amount of heterogeneity and the especially large $I^{2}$ statistic $\left(I^{2}>75\right)$, indicate that moderating factors are most likely affecting the relationship between FLCA and speaking academic achievement (Higgins et al., 2003).

\section{Moderator analyses}

The potential moderators of average age, female proportion of the sample, and institution type were examined for each form of academic achievement (see Table 1) - with the exception of listening academic achievement and FLCA as moderated by average age as too few studies reported an average age as to make an analysis viable.

No statistically significant moderating effects were found for any category of academic achievement with the exception of listening academic achievement. The moderator analysis indicates that the institution type was found to have a moderating effect on the relationship between listening academic achievement and FLCA (slope $=.294, Z=2.68, p=.007$ ). Thus, students learning a language at university indicated a stronger relationship between FLCA and listening academic achievement, than students in a language learning course in school. However, it should be noted that only a small amount of effect sizes were included in either analyses. Thus, the analysis did not meet the recommended minimum of $k=10$ (Green et al., 2008). Therefore, the possibility that the statistically significant results in regards to the moderator analyses of listening academic achievement and FLCA may be a Type I error ought to be considered. 
Thus, the moderators coded and analysed do not address or alleviate the large amounts of heterogeneity found in the initial meta-analysis results.

Table 1

Moderator Analyses.

\begin{tabular}{|c|c|c|c|c|c|}
\hline & $K$ & $n$ & Slope & $Z$ & $p$-value \\
\hline \multicolumn{6}{|c|}{ General Academic Achievement } \\
\hline Average Age & 30 & 5,871 & .022 & 1.72 & .085 \\
\hline Female Proportion & 41 & 10,045 & -.001 & -.59 & .553 \\
\hline Institution Type & 56 & 12,102 & -.014 & -.21 & .126 \\
\hline \multicolumn{6}{|c|}{ Reading Academic Achievement } \\
\hline Average Age & 6 & 655 & .005 & .45 & .653 \\
\hline Female Proportion & 8 & 829 & .001 & 1.05 & .292 \\
\hline Institution Type & 9 & 731 & -.017 & -.17 & .183 \\
\hline \multicolumn{6}{|c|}{ Writing Academic Achievement } \\
\hline Average Age & 6 & 1,000 & .018 & 1.27 & .205 \\
\hline Female Proportion & 5 & 932 & .000 & .11 & .906 \\
\hline Institution Type & 6 & 834 & .026 & .14 & .888 \\
\hline \multicolumn{6}{|c|}{ Listening Academic Achievement } \\
\hline Female Proportion & 6 & 926 & .013 & 1.22 & .220 \\
\hline Institution Type & 5 & 512 & .294 & 2.68 & $.007 *$ \\
\hline \multicolumn{6}{|c|}{ Speaking Academic Achievement } \\
\hline Average Age & 12 & 1,359 & -.054 & -1.81 & .069 \\
\hline Female Proportion & 13 & 1,263 & .004 & 1.63 & .103 \\
\hline Institution Type & 14 & 1,401 & -.255 & -1.57 & .116 \\
\hline
\end{tabular}

Note. ${ }^{*} p<.01$

\section{Publication bias analysis}

In order to assess the possibility of publication bias, a funnel plot was generated for each of the categories of academic achievement. The funnel plot for general academic achievement is presented in Figure 3 (for all other categories, see the Supplementary Materials). In addition, the trim-and-fill method in a random effects model was used on each category of academic achievement and FLCA (Duval \& Tweedie, 2000) (see Table 2).

Table 2

Publication Bias Analyses

\begin{tabular}{llll}
\hline & $K$ & $\begin{array}{l}\text { Summary Estimate } \\
{[95 \% \mathrm{CI}]}\end{array}$ & $\begin{array}{l}\text { Trim-and-Fill Estimate } \\
{[95 \% \mathrm{CI}]}\end{array}$ \\
\hline General Academic Achievement & 59 & $-.39[-.45 ;-.33]$ & $-.29[-.37 ;-.22]$ \\
Reading Academic Achievement & 10 & $-.34[-.41 ;-.28]$ & $-.32[-.38 ;-.25]$ \\
Writing Academic Achievement & 7 & $-.47[-.57 ;-.30]$ & $-.44[-.57 ;-.30]$
\end{tabular}


Journal for the Psychology of Language Learning, Volume 2, June 2020, pp. 26-56. ISSN: 2642-7001. http://www.iapll.com/journal

$\begin{array}{llll}\text { Listening Academic Achievement } & 7 & -.53[-.72 ;-.33] & -.41[-.63 ;-.20] \\ \text { Speaking Academic Achievement } & 16 & -.26[-.40 ;-.12] & -.19[-.33 ;-.07]\end{array}$

From the trim-and-fill results in Table 2 and the visual inspection of the funnel plot, it appears that all categories of academic achievement and FLCA are subject to publication bias to some extent. The calculated effect size $(r=-.39)$ of FLCA and general academic achievement differed to a large extent from the trim-and-fill estimated effect size $(r=-.29)$. However, the trim-and-fill results of FLCA and reading academic achievement $(r=-.34)$ seem to differ minimally from the summary effect $(r=-.32)$. The funnel plot of FLCA and reading academic achievement further confirms the rather small impact of publication bias, with all studies falling within the $95 \%$ confidence interval of the summary estimate.

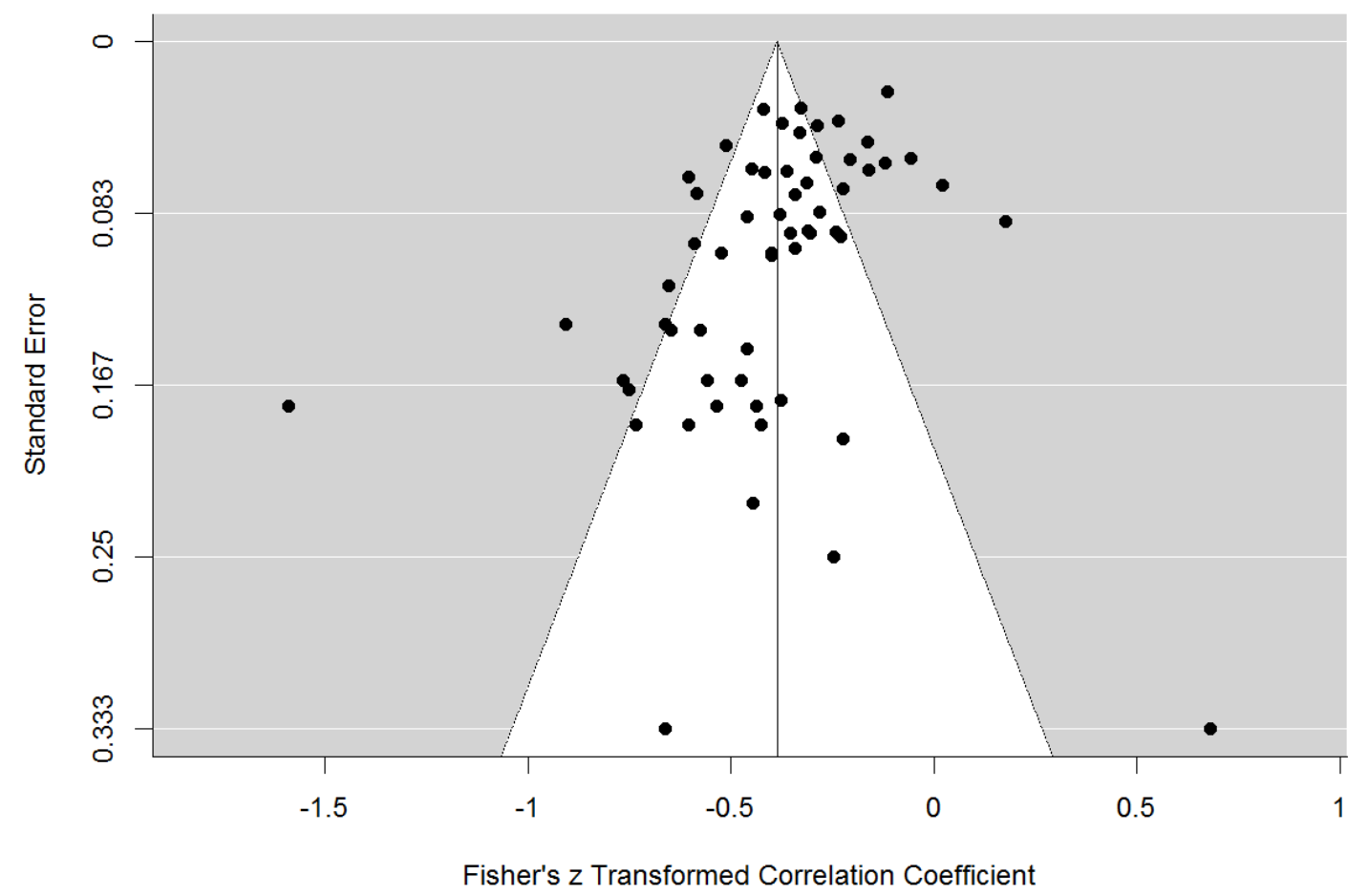

Figure 3. Funnel plot of General Academic Achievement.

Similarly, publication bias is indicated in the results of FLCA and writing-, listening-, and speaking academic achievement. The funnel plots of these three categories of academic achievement indicated several studies outside of the $95 \%$ confidence interval of the summary estimate and a wide dispersion of effect sizes (see Supplementary Materials). The trim-and-fill adjusted effect size of FLCA and writing academic achievement $(r=-.44)$ was slightly smaller 
than the original summary estimate $(r=-.47)$. The original summary estimate of FLCA and listening academic achievement ( $r=-.53)$ was also considerably larger than the suggested trimand-fill estimate $(r=-.41)$. Lastly, FLCA and speaking academic achievement summary estimate $(r=-.26)$ was also found to be indicative of publication bias with a trim-and-fill estimate of $r=-$ .19 .

\section{Summary of results}

The meta-analysis indicates moderate to large negative effect sizes for all categories of academic achievement and FLCA, with large confidence intervals indicating no statistically significant difference across categories (see Table 3). Thus, students experiencing FLCA are more likely to have a negative achievement score on all categories of academic achievement coded in this study.

Table 3

Meta-Analyses Results Summary

\begin{tabular}{llllll}
\hline & $K$ & $N$ & $r[95 \% C I]$ & $I^{2}$ & $\tau^{2}$ \\
\hline General Academic Achievement & 59 & 12,858 & $-.39[-.45 ;-.33]$ & 90.36 & .05 \\
Reading Academic Achievement & 10 & 995 & $-.34[-.41 ;-.28]$ & 15.87 & .00 \\
Writing Academic Achievement & 7 & 1,098 & $-.47[-.57 ;-.30]$ & 75.41 & .02 \\
Listening Academic Achievement & 7 & 986 & $-.53[-.72 ;-.33]$ & 87.86 & .06 \\
Speaking Academic Achievement & 16 & 1,745 & $-.26[-.45 ;-.33]$ & 86.86 & .07 \\
\hline
\end{tabular}

\section{Discussion}

The results of this meta-analysis confirmed the negative relationship between FLCA and academic achievement. General academic achievement as measured by grade point averages or test scores shared a moderate negative correlation with FLCA $(r=-.39 ; k=59 ; N=12,858)$, confirming the observation made by Horwitz (2001) in her review of FLCA. In addition, the overall effect size found for general academic achievement was markedly similar to the one found in the meta-analysis of Teimouri et al. (2019) of $r=-.36(k=105 ; N=19,933)$. Although it should be noted that the meta-analysis conducted by Teimouri et al. (2019) was a broader study on general second language anxiety and academic achievement, and as such only 33 of the 67 studies included in this meta-analysis were also captured by Teimouri et al. (2019). 
Furthermore, the results indicate that individual categories of competence are negatively related to FLCA. Reading-, writing-, listening-, and speaking academic achievement has each been separately and negatively linked to FLCA (see Table 3). Reading academic achievement shared a moderate negative correlation with FLCA $(r=-.34 ; k=10 ; N=995)$, similar to the results of general academic achievement. Whereas writing academic achievement and listening academic achievement shared moderately large correlations with FLCA $(r=-.44 ; k=7 ; N=$ 1,098) $(r=-.53 ; k=7 ; N=986)$. However, it should be noted that the $95 \%$ confidence interval of both writing and reading academic achievement are quite large and the small number of studies included in the analyses impacts the statistical confidence of the result. As all categories of academic achievement's confidence intervals overlap, it cannot be concluded that different competency categories are differently associated with FLCA. Interestingly though, and on a purely descriptive level, speaking academic achievement had the lowest correlation with FLCA $(r=-.26 ; k=16 ; N=1,745)$, even though speaking in the foreign language is often cited as a particular source of FLCA (Phillips, 1992). However, the analysis between speaking academic achievement and FLCA did indicate a large amount of heterogeneity, thus the relationship may be exacerbated or impeded by other factors such as a general public speaking anxiety. Indeed, all categories of academic achievement and FLCA showed large amounts of heterogeneity (see Table 3) - with the exception of reading academic achievement - indicating the relationships to be complex and most likely influenced by moderators.

The moderators coded in this analysis did not provide additional insight into the complexity of FLCA and academic achievement. The average age, female proportion of the sample, as well as the institution type were found to not significantly moderate the relationships between FLCA and the different categories of academic achievement - with the exception of FLCA and listening academic achievement as moderated by institution type $(Z=.294 ; p<.01)$. However, as the number of effect sizes included in the analysis were very small $(k=5)$ and no other comparable result could be found in any other category of academic achievement, it is therefore highly likely that this positive result may be a Type I error of a false positive finding. On the other hand, the majority of moderator analyses, as well as primary analyses of writing and listening academic achievement, can perhaps be considered underpowered due to the low amount of studies included in the analyses. This increases the probability of not only Type I errors, but also Type II errors with the possibility of a true finding being dismissed. The low sample sizes 
and small amount of studies in the field under scrutiny - such as the specific academic competencies - therefore create errors that may permeate through the findings of the metaanalysis.

Future research efforts are therefore needed in order to establish variables that moderate the relationship between foreign language anxiety and academic achievement. In addition, as age, gender and instruction context have all been identified as possible moderators in the literature (Abu-Rabia, 2004; Dewaele, 2007; Kim, 2009), future research regarding these variables and their complex and possibly dynamic relation to FLCA and academic achievement is also recommended. Indeed, more may be understood regarding individual differences and academic achievement in foreign language learning by expanding the scope of the meta-analysis to include other variables in the FLCA nomological network such as self-perceived competence, willingness to communicate and foreign language enjoyment. A meta-analytic structural equation model on such variables is therefore highly recommended.

Future research efforts should also extend to further examining the directionality in the relationship between FLCA and academic achievement. The relationship between the two variables has been described as a "vicious circle" (Cheng, Horwitz, \& Schallert, 1999, p. 437), and future studies examining causality between FLCA and academic achievement would make a valuable contribution.

Beyond directionality, the question of malleability ought to be further addressed. This meta-analysis established that students with higher levels of FLCA are placed at a disadvantage as they are more probable to have lower achievement scores than their lower-level FLCA peers. This can have a detrimental effect on the success of a student in a high stakes test environment, where admission to schools or programs is dependent on grades or exam scores. Encouraging findings have been made throughout the years, with both teacher and learner strategies developed to reduce the presence of FLCA in learners (Oxford, 2017). Thus, continued research on the reduction and management of FLCA as well as the acknowledgement of its presence in the foreign language learning process should remain a focus point in the pedagogy of individual differences in language learning. 


\section{Limitations}

The study has several limitations that ought to be considered. Firstly, in the methods of the meta-analysis, several studies were excluded due to lack of necessary statistical data or because no full-text could be located. Efforts were made to contact authors in such cases, however, there was only one fruitful reply. In addition, non-English publications were excluded. It is also highly likely that unpublished data on the variables that could have been added to the meta-analysis exists due to the popularity of the topic in applied linguistics. The number of studies included in the meta-analysis may therefore not represent the entirety of the research on the subject, however we have confidence that the meta-analysis captured a significant portion of existing studies.

Secondly, the current meta-analysis examined language anxiety solely through the lens of the Foreign Language Classroom Anxiety Scale (FLCAS), one specific measurement instrument. The findings of the meta-analysis are therefore limited to foreign language classroom anxiety as defined and designed by Horwitz et al. (1986). A broader meta-analysis encompassing all possible measures of language anxiety has been conducted and can inform interested readers on the relation between FLCA as measured through different instruments and academic achievement (see Teimouri et al., 2019). In addition, translated and shortened versions of the FLCAS were included in the analyses, and as such may not necessarily capture the broad context of the original 33-item FLCAS.

Thirdly, the large amount of heterogeneity identified in the analyses indicates more complexity in the relationship between FLCA and academic achievement than can be captured by correlation coefficients. In addition, the moderators coded in the analyses did not alleviate unexplained variance. Future studies examining moderators in terms of individual differences variables (foreign language enjoyment, willingness to communicate, and self-perceived competence), as well as sample characteristics (level of multilingualism, SES, culture) is therefore needed.

The small amount of studies in the specific competency-based achievement measures (reading-, writing-, listening-, and speaking academic achievement) implies that caution ought to be given in the interpretation of results. The publication bias results of these analyses further implies that the small number of studies did impact the strength of correlations. This caution 
should also be extended to the moderator analyses, where small numbers of effect sizes undoubtedly created instability in the results.

\section{Conclusion}

It is clear that FLCA, as measured by the FLCAS, is as prevalent in language learning today as it was at the inception of the variable in 1986. The negative relationship between FLCA and academic achievement found in this meta-analysis confirms the negative parallel occurrence that both anxiety and low achievement can have in the language learning classroom. With this result in mind, we urge researchers to further examine the directionality of the relationship between language anxiety and academic achievement, and subsequently investigate methods of reducing or managing anxiety in the language learning process. Efforts to minimise its negative impact ought to be made and, subsequently, potential effects on achievement should be investigated. This is especially a concern as low achievement scores can result in real-world negative consequences for language learners. We therefore hope that this meta-analysis can provide a useful evidence-based guide for language instructors, designers of language learning courses and materials, as well as researchers on the importance of individual differences such as FLCA and that it relates to achievement in language learning.

\section{References}

Abu-Rabia, S. (2004). Teachers' role, learners' gender differences, and FL anxiety among Seventh-grade students studying English as a FL. Educational Psychology, 24(5), 711721. https://doi.org/10.1080/0144341042000263006

Aida, Y. (1994). Examination of Horwitz, Horwitz, and Cope's construct of foreign language anxiety: The case of students of Japanese. The Modern Language Journal, 78(2), 155168. https://doi.org/10.1111/j.1540-4781.1994.tb02026.x

Alidoost, Y., Mirchenari, N. A. N., \& Mehr, S. H. (2013). The effects of anxiety on Iranian EFL learners' performance on final achievement test in English classes of high schools. International Journal of Language Learning and Applied Linguistics World, 4(3), 284292.

Alrabai, F. (2015). The influence of teachers' anxiety-reducing strategies on learners' foreign language anxiety. Innovation in Language Learning and Teaching, 9(2), 163-190. https://doi.org/10.1080/17501229.2014.890203 
Amiri, M., \& Ghonsooly, B. (2015). The relationship between English learning anxiety and the students' achievement on examinations. Journal of Language Teaching and Research, 6(4), 855-865. https://doi.org/10.17507/j1tr.0604.20

Atasheneh, N., \& Izadi, A. (2012). The role of teachers in reducing/increasing listening comprehension test anxiety: A case of Iranian EFL learners. English Language Teaching, 5(3), 178-187.

Baker, S. C., \& MacIntyre, P. D. (2000). The role of gender and immersion in communication and second language orientations. Language Learning, 50(2), 311-341. https://doi.org/10.1111/0023-8333.00119

Bayerl, P. S., \& Paul, K. I. (2011). What determines inter-coder agreement in manual annotations? A meta-analytic investigation. Computational Linguistics, 37(4), 699-725. https://doi.org/10.1162/COLI_a_00074

Borenstein, M., Hedges, L. V., Higgins, J. P. T., \& Rothstein, H. R. (2011). Introduction to metaanalysis. Chichester (UK): John Wiley.

Burden, P. (2004). The teacher as facilitator: Reducing anxiety in the EFL university classroom. JALT Hokkaido Journal, 8(1), 3-18.

Chen, I.-J., \& Chang, C.-C. (2009). Cognitive load theory: An empirical study of anxiety and task performance in language learning. Electronic Journal of Research in Educational Psychology, 7(2), 729-746.

Cheng, Y., Horwitz, E. K., \& Schallert, D. L. (1999). Language anxiety: Differentiating writing and speaking components. Language Learning, 49(3), 417-446.

https://doi.org/10.1111/0023-8333.00095

Cheng, Y.-S. (2004). A measure of second language writing anxiety: Scale development and preliminary validation. Journal of Second Language Writing, 13(4), 313-335. https://doi.org/10.1016/j.jslw.2004.07.001

Clément, R., Gardner, R. C., \& Smythe, P. C. (1977). Motivational variables in second language acquisition: A study of Francophones learning English. Canadian Journal of Behavioural Science / Revue Canadienne Des Sciences Du Comportement, 9(2), 123-133. https://doi.org/10.1037/h0081614

Conn, V. S., Valentine, J. C., Cooper, H. M., \& Rantz, M. J. (2003). Grey literature in metaanalyses. Nursing Research, 52(4), 256-261.

Dewaele, J.-M. (2002). Psychological and sociodemographic correlates of communicative anxiety in L2 and L3 production. International Journal of Bilingualism, 6(1), 23-38. https://doi.org/10.1177/13670069020060010201 
Dewaele, J.-M. (2007). The effect of multilingualism, sociobiographical, and situational factors on communicative anxiety and foreign language anxiety of mature language learners.

International Journal of Bilingualism, 11(4), 391-409. https://doi.org/10.1177/13670069070110040301

Dewaele, J.-M. \& Al-Saraj, T. (2015). Foreign language classroom anxiety of Arab learners of English: The effect of personality, linguistic and sociobiographical variables. Studies in Second Language Learning and Teaching, 5(2), 205-230. https://doi.org/10.14746/ssllt.2015.5.2.2

Dewaele, J.-M., \& MacIntyre, P. (2014). The two faces of Janus? Anxiety and enjoyment in the foreign language classroom. Studies in Second Language Learning and Teaching, 4(2), 237-274. doi:10.14746/ssllt.2014.4.2.5

Dewaele, J.-M., Petrides, K. V., \& Furnham, A. (2008). Effects of trait emotional intelligence and sociobiographical variables on communicative anxiety and foreign language anxiety among adult multilinguals: A review and empirical investigation. Language Learning, 58(4), 911-960. https://doi.org/10.1111/j.1467-9922.2008.00482.x

Dordinejad, G. F., \& Ahmadabad, M. R. (2014). Examination of the relationship between foreign language classroom anxiety and English cchievement among male and female Iranian high school students. International Journal of Language Learning and Applied Linguistics World, 6(4), 446-460.

Dörnyei, Z., \& Ryan, S. (2015). The psychology of the language learner revisited. New York, NY: Routledge.

Duval, S., \& Tweedie, R. (2000). A nonparametric "trim and fill" method of accounting for publication bias in meta-analysis. Journal of the American Statistical Association, 95(449), 89-98. https://doi.org/10.1080/01621459.2000.10473905

Ehrman, M. E., Leaver, B. L., \& Oxford, R. L. (2003). A brief overview of individual differences in second language learning11The content of this article does not represent official policy of the U.S. Department of State; the observations and opinions are those of the author. System, 31(3), 313-330. https://doi.org/10.1016/S0346-251X(03)00045-9

Elkhafaifi, H. (2005). Listening comprehension and anxiety in the Arabic language classroom. The Modern Language Journal, 89(2), 206-220. https://doi.org/10.1111/j.15404781.2005.00275.x

Field, A. (2005). Discovering statistics using SPSS (2 ${ }^{\text {nd }}$ ed.). London, UK: Sage Publications.

Field, A. P. (2001). Meta-analysis of correlation coefficients: A Monte Carlo comparison of fixed- and random-effects methods. Psychological Methods, 6(2), 161-180. https://doi.org/10.1037/1082-989X.6.2.161 
Frenzel, A. C., Pekrun, R., \& Goetz, T. (2007). Perceived learning environment and students' emotional experiences: A multilevel analysis of mathematics classrooms. Learning and Instruction, 5(17), 478-493. https://doi.org/10.1016/j.learninstruc.2007.09.001

Gardner, R. C. (1985). Social psychology and second language learning: The role of attitudes and motivation. Baltimore, MA: Edward Arnold.

Gardner, R. C., \& MacIntyre, P. D. (1991). An instrumental motivation in language study: Who says it isn't effective? Studies in Second Language Acquisition, 13(1), 57-72. https://doi.org/10.1017/S0272263100009724

Gardner, R. C., \& MacIntyre, P. D. (1993). A student's contributions to second-language learning. Part II: Affective variables. Language Teaching, 26(1), 1-11. https://doi.org/10.1017/S0261444800000045

Gardner, R. C., \& Smythe, P. C. (1975). Motivation and second-language acquisition. Canadian Modern Language Review, 31(3), 218-233. https://doi.org/10.3138/cmlr.31.3.218

Gardner, R. C., Smythe, P. C., Clément, R., \& Gliksman, L. (1976). Second-language learning: A social psychological perspective. Canadian Modern Language Review, 32(3), 198213. https://doi.org/10.3138/cmlr.32.3.198

Gardner, R. C., Tremblay, P. F., \& Masgoret, A.-M. (1997). Towards a full model of second language learning: An empirical investigation. The Modern Language Journal, 81(3), 344-362. https://doi.org/10.1111/j.1540-4781.1997.tb05495.x

Gocer, A. (2014). The relationship between anxiety and attitude of students learning Turkish as a foreign language and their achievement on target language. Educational Research and Reviews, 9(20), 879-884.

Green, S., Higgins, J. P. T., Alderson, P., Clarke, M., Mulrow, C. D., \& Oxman, A. D. (2008). Cochraine handbook for systematic reviews of interventions: Vol. 5.0.2 (S. Green \& J. P. T. Higgins, Eds.). Chichester, UK: John Wiley.

Hedges, L. V., \& Olkin, I. (1985). Statistical methods for meta-analysis. San Diego, CA: Academic Press.

Higgins, J. P. T., Thompson, S. G., Deeks, J. J., \& Altman, D. G. (2003). Measuring inconsistency in meta-analyses. BMJ, 327(7414), 557-560. https://doi.org/10.1136/bmj.327.7414.557

Horwitz, E. K. (1986). Preliminary evidence for the reliability and validity of a foreign language anxiety scale. TESOL Quarterly, 20(3), 559-562. https://doi.org/10.2307/3586302 
Horwitz, E. K. (2000). It ain't over 'til it's over: On foreign language anxiety, first language deficits, and the confounding of variables. The Modern Language Journal, 84(2), 256259. 10.1111/0026-7902.00067

Horwitz, E. (2001). Language anxiety and achievement. Annual Review of Applied Linguistics, 21, 112-126. https://doi.org/10.1017/S0267190501000071

Horwitz, E. K. (2017). On the misreading of Horwitz, Horwitz and Cope (1986) and the need to balance anxiety research and the experiences of anxious language learners. In C. Gkonou, M. Daubney, \& J.-M. Dewaele (Eds.), New insights into language anxiety: Theory, research and educational implications (pp. 31-47). Bristol, UK: Multilingual Matters.

Horwitz, E. K., Horwitz, M. B., \& Cope, J. (1986). Foreign language classroom anxiety. The Modern Language Journal, 70(2), 125-132. https://doi.org/10.1111/j.15404781.1986.tb05256.x

Hunter, J. E., \& Schmidt, F. L. (2004). Methods of meta-analysis: Correcting error and bias in research findings. Thousand Oaks, CA: SAGE.

Jee, M. J. (2014). Affective factors in Korean as a foreign language: Anxiety and beliefs. Language, Culture and Curriculum, 27(2), 182-195. https://doi.org/10.1080/07908318.2014.918626

Jee, M. J. (2016). Exploring Korean heritage language learners' anxiety: 'We are not afraid of Korean!' Journal of Multilingual and Multicultural Development, 37(1), 56-74. https://doi.org/10.1080/01434632.2015.1029933

Khodadady, E., \& Khajavy, G. H. (2013). Exploring the role of anxiety and motivation in foreign language achievement: A structural equation modeling approach. Porta Linguarum, 20, 269-286.

Kim, J.-H. (2000). Foreign language listening anxiety: A study of Korean students learning English (Unpublished doctoral dissertation). University of Texas at Austin, Austin, Texas.

Kim, S.-Y. (2009). Questioning the stability of foreign language classroom anxiety and motivation across different classroom contexts. Foreign Language Annals, 42(1), 138 157. https://doi.org/10.1111/j.1944-9720.2009.01012.x

Legac, V. (2007). Foreign-language anxiety and listening skill in Croatian monolingual and bilingual students of EFL. In J. Horváth \& M. Nikolov (Eds.), UPRT 2007: Empirical Studies in English Applied Linguistics (pp. 217-243). Pécs: Lingua Franca Csoport.

Liu, M., \& Huang, W. (2011). An exploration of foreign language anxiety and English learning motivation. Education Research International, 2011, 1-8. https://doi.org/10.1155/2011/493167 
Liu, M., \& Jackson, J. (2008). An exploration of Chinese EFL learners' unwillingness to communicate and foreign language anxiety. The Modern Language Journal, 92(1), 7186. https://doi.org/10.1111/j.1540-4781.2008.00687.x

Love, J., Dropmann, D., \& Selker, R. (2018). Jamovi (Version 0.9) [Computer software]. Jamovi Project. https://www.jamovi.org

Macintyre, P. D. (1995a). How does anxiety affect second language learning? A reply to Sparks and Ganschow. The Modern Language Journal, 79(1), 90-99. https://doi.org/10.1111/j.1540-4781.1995.tb05418.x

MacIntyre, P. D. (1995b). On seeing the forest and the trees: A rejoinder to Sparks and Ganschow. The Modern Language Journal, 79(2), 245-248. https://doi.org/10.2307/329623

MacIntyre P. D. (2017). An overview of language anxiety research and trends in its development. In C. Gkonou, M. Daubney \& J.-M. Dewaele (Eds.), New insights into language anxiety: Theory, research and educational implications (pp. 11-30). Bristol UK: Multilingual Matters.

MacIntyre, P. D., Baker, S. C., Clément, R., \& Donovan, L. A. (2002). Sex and age effects on willingness to communicate, anxiety, perceived competence, and L2 motivation among junior high school French immersion students. Language Learning, 52(3), 537-564. https://doi.org/10.1111/1467-9922.00194

MacIntyre, P. D., Baker, S., Clément, R., \& Donovan, L. (2003). Talking in order to learn: Willingness to communicate and intensive language programs. Canadian Modern Language Review, 59(4), 589-608. https://doi.org/10.3138/cmlr.59.4.589

MacIntyre, P. D., \& Gardner, R. C. (1989). Anxiety and second-language learning: Toward a theoretical clarification. Language Learning, 39(2), 251-275. https://doi.org/10.1111/j.1467-1770.1989.tb00423.x

Matsuda, S., \& Gobel, P. (2004). Anxiety and predictors of performance in the foreign language classroom. System, 32(1), 21-36. https://doi.org/10.1016/j.system.2003.08.002

Moher D., Liberati A., Tetzlaff J., Altman D.G., \& and the PRISMA Group (2009). Preferred reporting items for systematic reviews and meta-analyses: The prisma statement. Annals of Internal Medicine, 151(4), 264-269. https://doi.org/10.7326/0003-4819-151-4200908180-00135

Onwuegbuzie, A. J., Bailey, P., \& Daley, C. E. (1999). Factors associated with foreign language anxiety. Applied Psycholinguistics, 20(2), 217-239. https://doi.org/10.1017/S0142716499002039 
Oxford, R.L. (2017). Anxious language learners can change their minds: Ideas and strategies from traditional psychology and Positive Psychology. In C. Gkonou, M. Daubney \& J.M. Dewaele (Eds.), New insights into language anxiety: Theory, research and educational implications (pp. 177-197). Bristol, UK: Multilingual Matters.

Park, G.-P., \& French, B. F. (2013). Gender differences in the foreign language classroom anxiety scale. System, 41(2), 462-471. https://doi.org/10.1016/j.system.2013.04.001

Phillips, E. M. (1992). The effects of language anxiety on students' oral test performance and attitudes. The Modern Language Journal, 76(1), 14-26. https://doi.org/10.1111/j.15404781.1992.tb02573.x

Rodríguez, M., \& Abreu, O. (2003). The stability of general foreign language classroom anxiety across English and French. The Modern Language Journal, 87(3), 365-374. https://doi.org/10.1111/1540-4781.00195

Roos, A.-L., Bieg, M., Goetz, T., Frenzel, A. C., Taxer, J., \& Zeidner, M. (2015). Experiencing more mathematics anxiety than expected? Contrasting trait and state anxiety in high achieving students. High Ability Studies, 26(2), 245-258. https://doi.org/10.1080/13598139.2015.1095078

Rosenberg, M. S. (2005). The file drawer problem revisited: A general weighted method for calculating fail-safe numbers in meta-analysis. Evolution, 59(2), 464-468. https://doi.org/10.1111/j.0014-3820.2005.tb01004.x

Saito, Y., Garza, T. J., \& Horwitz, E. K. (1999). Foreign language reading anxiety. The Modern Language Journal, 83(2), 202-218. https://doi.org/10.1111/0026-7902.00016

Samimy, K. K., \& Tabuse, M. (1992). Affective variables and a less commonly taught language: A study in beginning Japanese classes. Language Learning, 42(3), 377-398. https://doi.org/10.1111/j.1467-1770.1992.tb01341.x

Satar, H. M., \& Özdener, N. (2008). The effects of synchronous CMC on speaking proficiency and anxiety: Text versus voice chat. The Modern Language Journal, 92(4), 595-613. https://doi.org/10.1111/j.1540-4781.2008.00789.x

Sellers, V. D. (2000). Anxiety and reading comprehension in Spanish as a foreign language. Foreign Language Annals, 33(5), 512-520. https://doi.org/10.1111/j.19449720.2000.tb01995.x

Sparks, R. L., \& Ganschow, L. (1995). A strong inference approach to causal factors in foreign language learning: A response to MacIntyre. The Modern Language Journal, 79(2), 235244. https://doi.org/10.1111/j.1540-4781.1995.tb05436.x

Sparks, R. L., \& Ganschow, L. (2007). Is the foreign language classroom anxiety scale measuring anxiety or language skills? Foreign Language Annals, 40(2), 260-287. https://doi.org/10.1111/j.1944-9720.2007.tb03201.x 
Sparks, R. L., Patton, J., Ganschow, L., \& Humbach, N. (2009). Long-term relationships among early first language skills, second language aptitude, second language affect, and later second language proficiency. Applied Psycholinguistics, 30(4), 725-755. https://doi.org/10.1017/S0142716409990099

Tanielian, A. R. (2014). Foreign language anxiety in a new English program in Thailand. International Education Journal: Comparative Perspectives, 13(1), 60-81.

Teimouri, Y., Goetze, J., \& Plonsky, L. (2019). Second language anxiety and achievement: A meta-analysis. Studies in Second Language Acquisition, 41(2), 489-489. https://doi.org/10.1017/S0272263118000311

Tóth, Z. (2007). Predictors of foreign-language anxiety: Examining the relationship between anxiety and other individual learner variables. In J. Horváth \& M. Nikolov (Eds.), UPRT 2007: Empirical studies in English applied linguistics (pp. 123-148). Pécs, Hungary: Lingua Franca Csoport.

Tóth, Z. (2008). A foreign language anxiety scale for Hungarian learners of English. Working Papers in Language Pedagogy, 2, 55-78.

Viechtbauer, W. (2010). Conducting meta-analyses in R with the metafor package. Journal of Statistical Software, 36(1), 1-48. https://doi.org/10.18637/jss.v036.i03

Vo, T. D., Samoilova, V., \& Wilang, J. D. (2017). Debilitating effects of anxiety on engineering students' language performances (pp. 275-285). Proceedings of the 3rd International Conference on Innovation in Education. Mahidol University, Thailand.

Woodrow, L. (2006). Anxiety and speaking English as a second language. RELC Journal, 37(3), 308-328. https://doi.org/10.1177/0033688206071315

Zan, R., Brown, L., Evans, J., \& Hannula, M. S. (2006). Affect in mathematics education: An introduction. Educational Studies in Mathematics, 63(2), 113-121.

Zessin, U., Dickhäuser, O., \& Garbade, S. (2015). The relationship between self-compassion and well-being: A meta-analysis. Applied Psychology: Health and Well-Being, 7(3), 340-364. https://doi.org/10.1111/aphw.12051 
International Association for the Psychology of Language Learning (IAPLL)

Journal for the Psychology of Language Learning

ISSN: 2642-7001. http://www.iapll.com/journal

Volume 2, June 2020, Botes, Dewaele, \& Greiff supplementary materials.

\section{Supplementary Materials}

\section{General Academic Achievement}

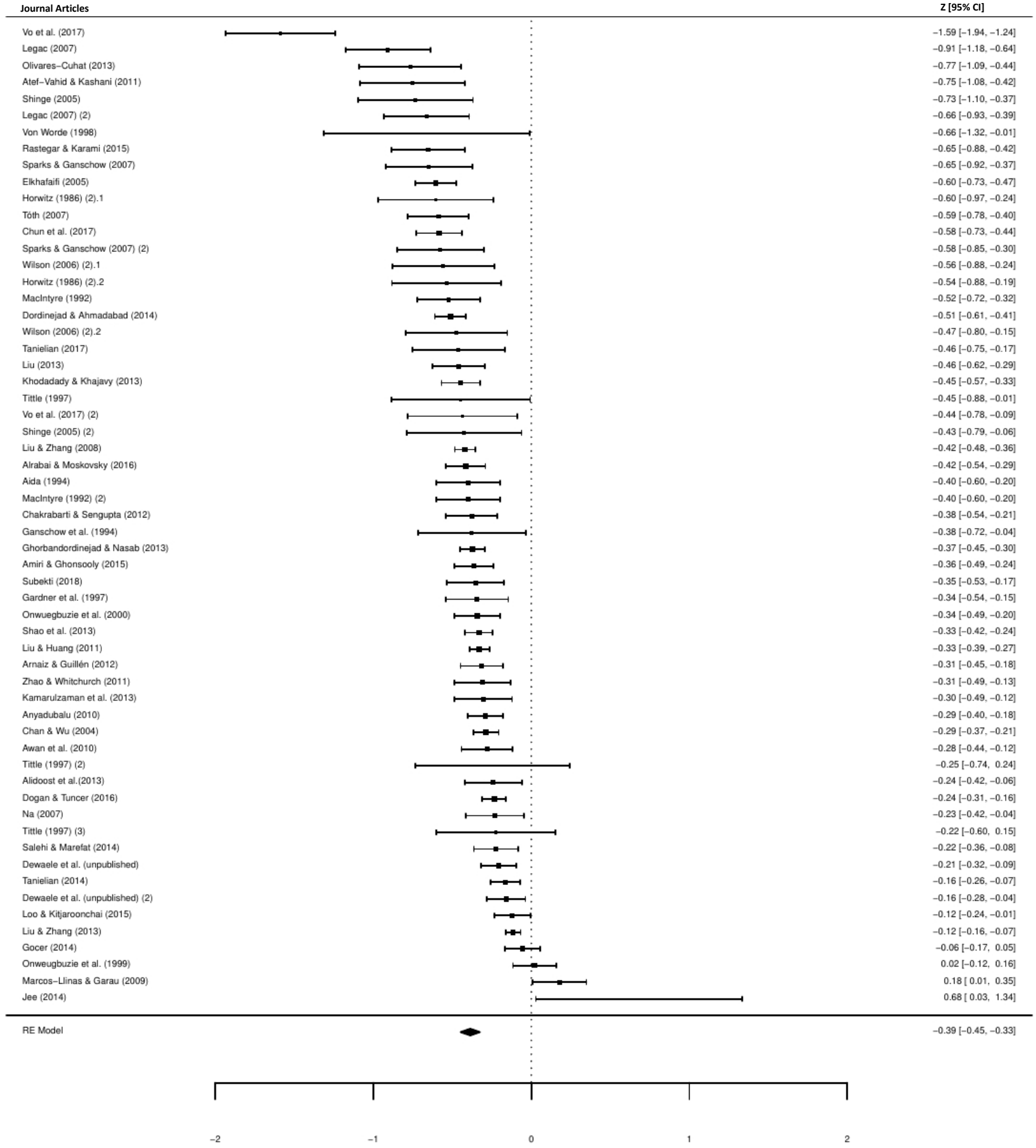

Figure 1. Fisher's Z transformed correlation coefficient forest plot of General Academic Achievement. 
Journal for the Psychology of Language Learning, Volume 2, June 2020, Botes, Dewaele, \& Greiff supplementary materials. ISSN: 2642-7001. http://www.iapll.com/journal

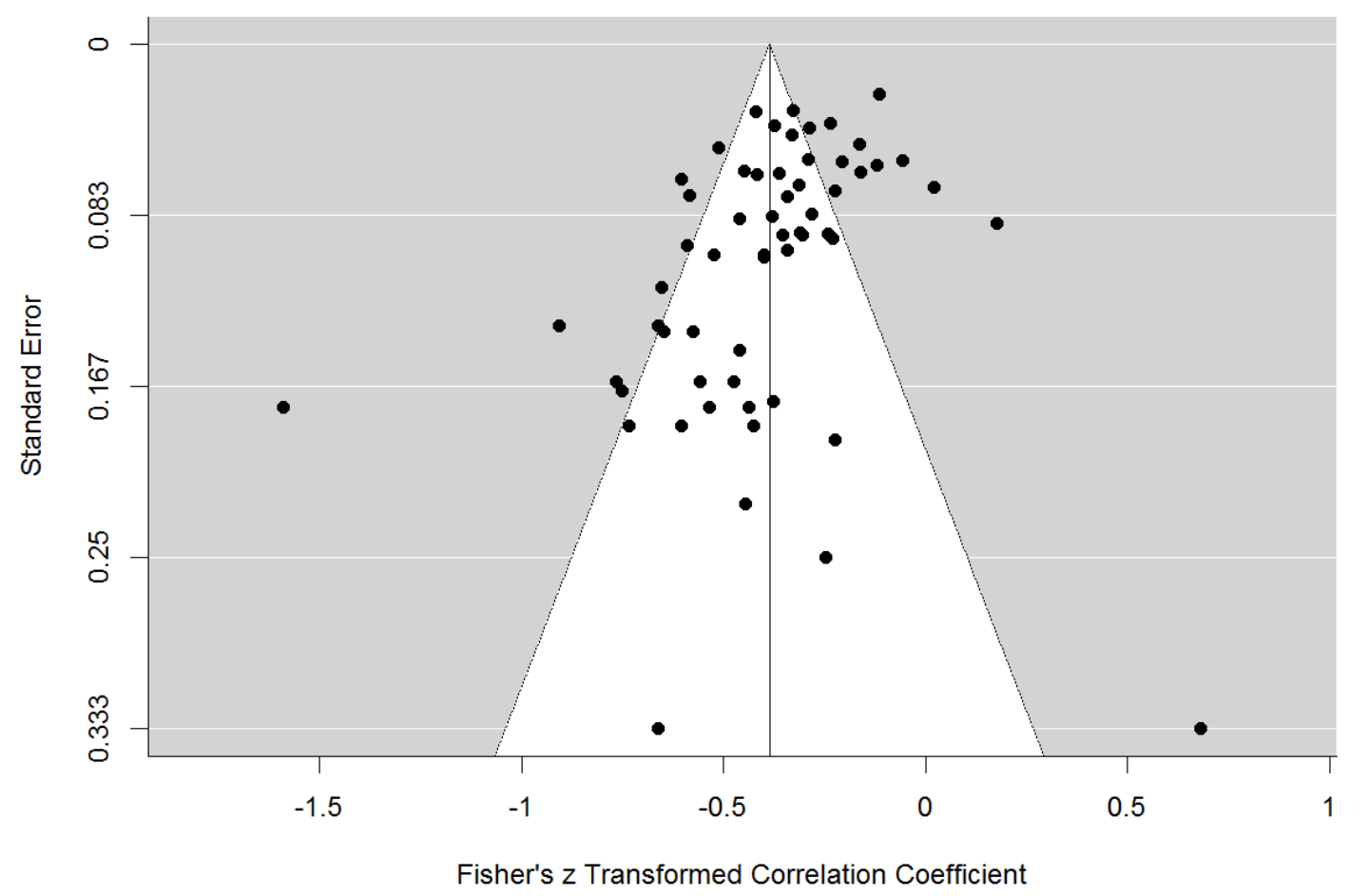

Figure 2. Funnel plot of General Academic Achievement. 
Journal for the Psychology of Language Learning, Volume 2, June 2020, Botes, Dewaele, \& Greiff supplementary materials. ISSN: 2642-7001. http://www.iapll.com/journal

\section{Reading Academic Achievement}

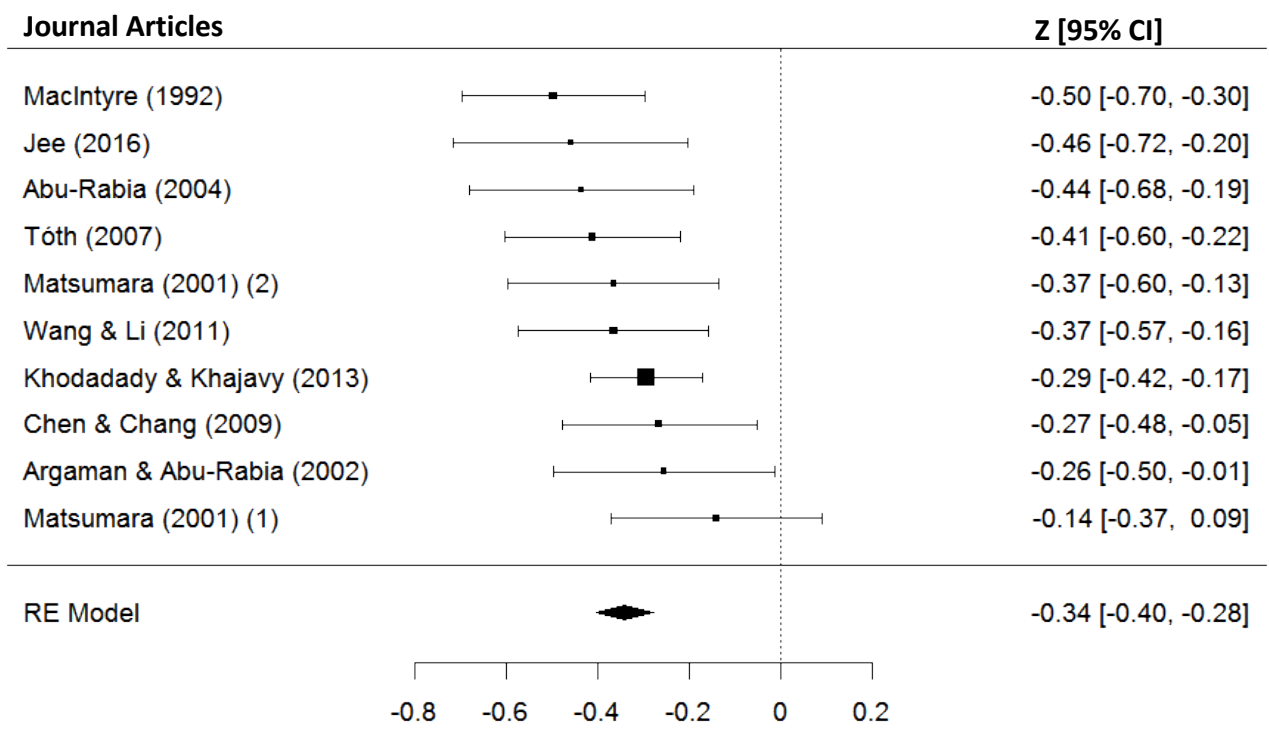

Figure 3. Fisher's Z transformed correlation coefficient forest plot of Reading Academic Achievement.

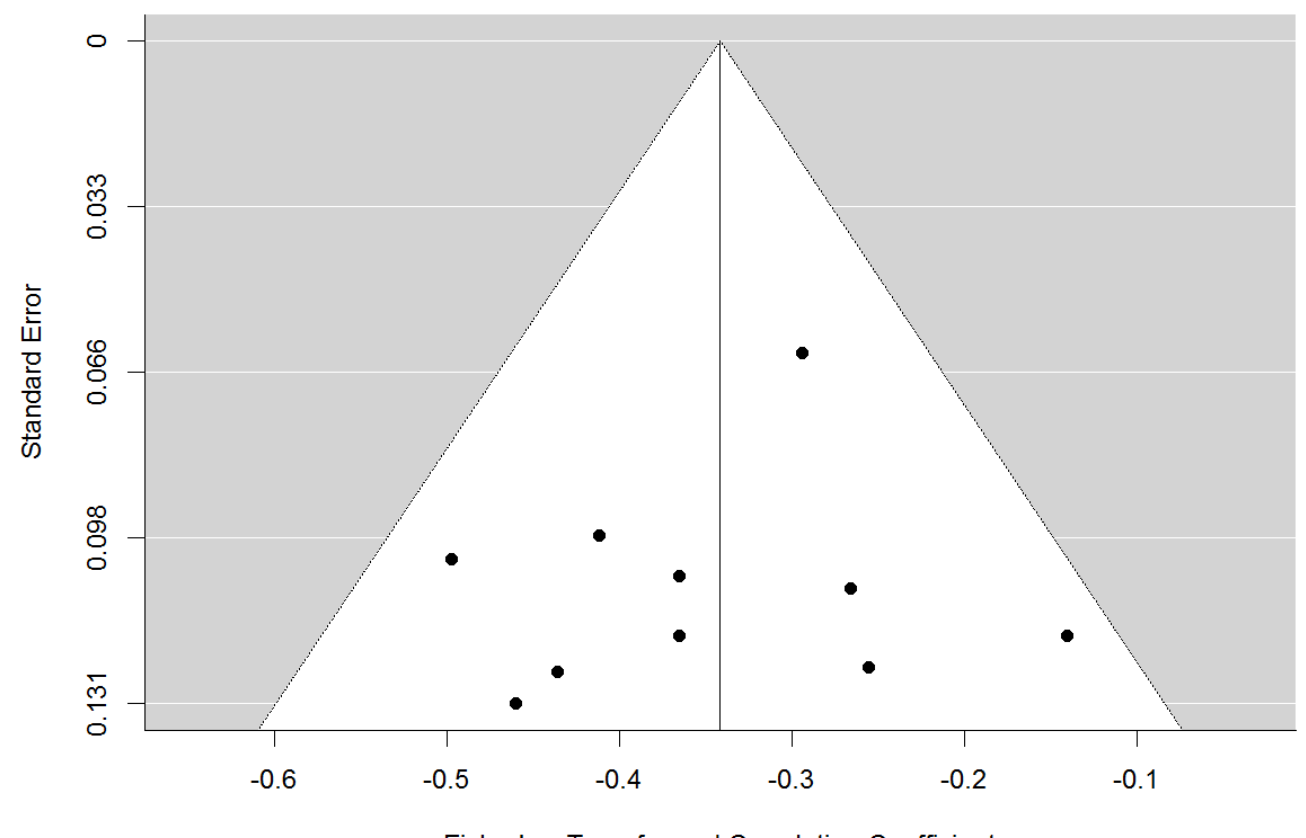

Fisher's z Transformed Correlation Coefficient

Figure 4. Funnel plot of Reading Academic Achievement. 
Journal for the Psychology of Language Learning, Volume 2, June 2020, Botes, Dewaele, \& Greiff supplementary materials. ISSN: 2642-7001. http://www.iapll.com/journal

\section{Writing Academic Achievement}

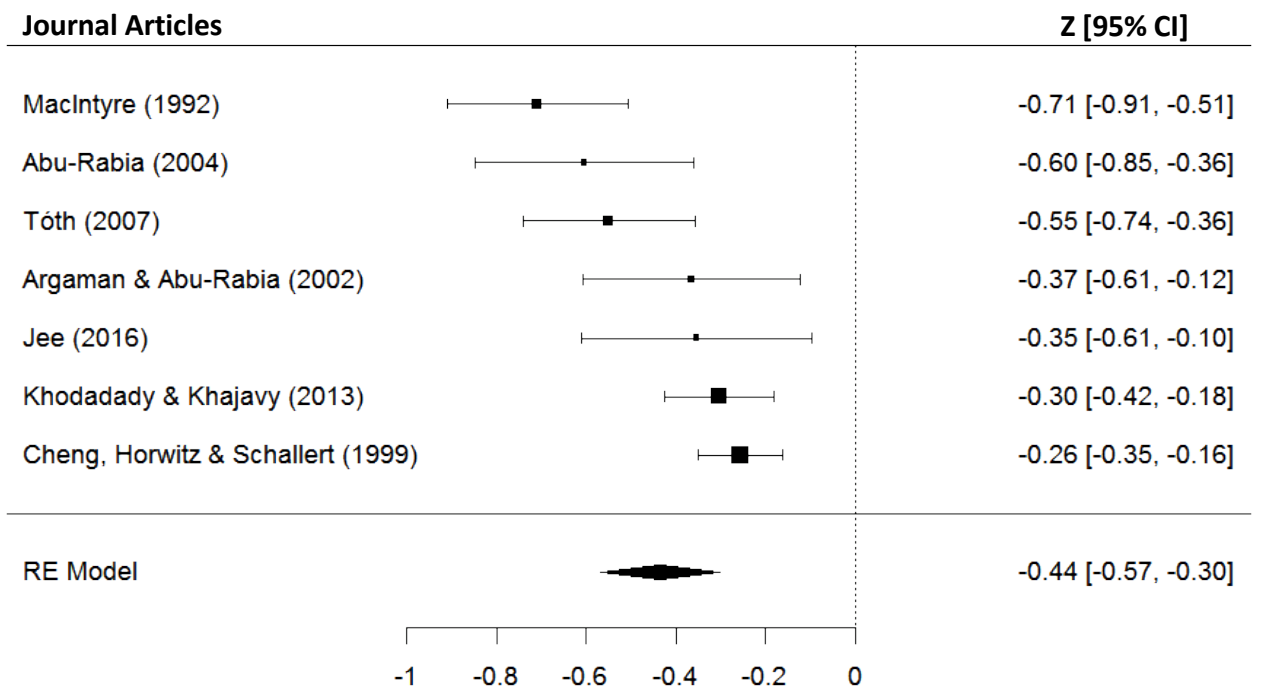

Figure 5. Fisher's Z transformed correlation coefficient forest plot of Writing Academic Achievement.

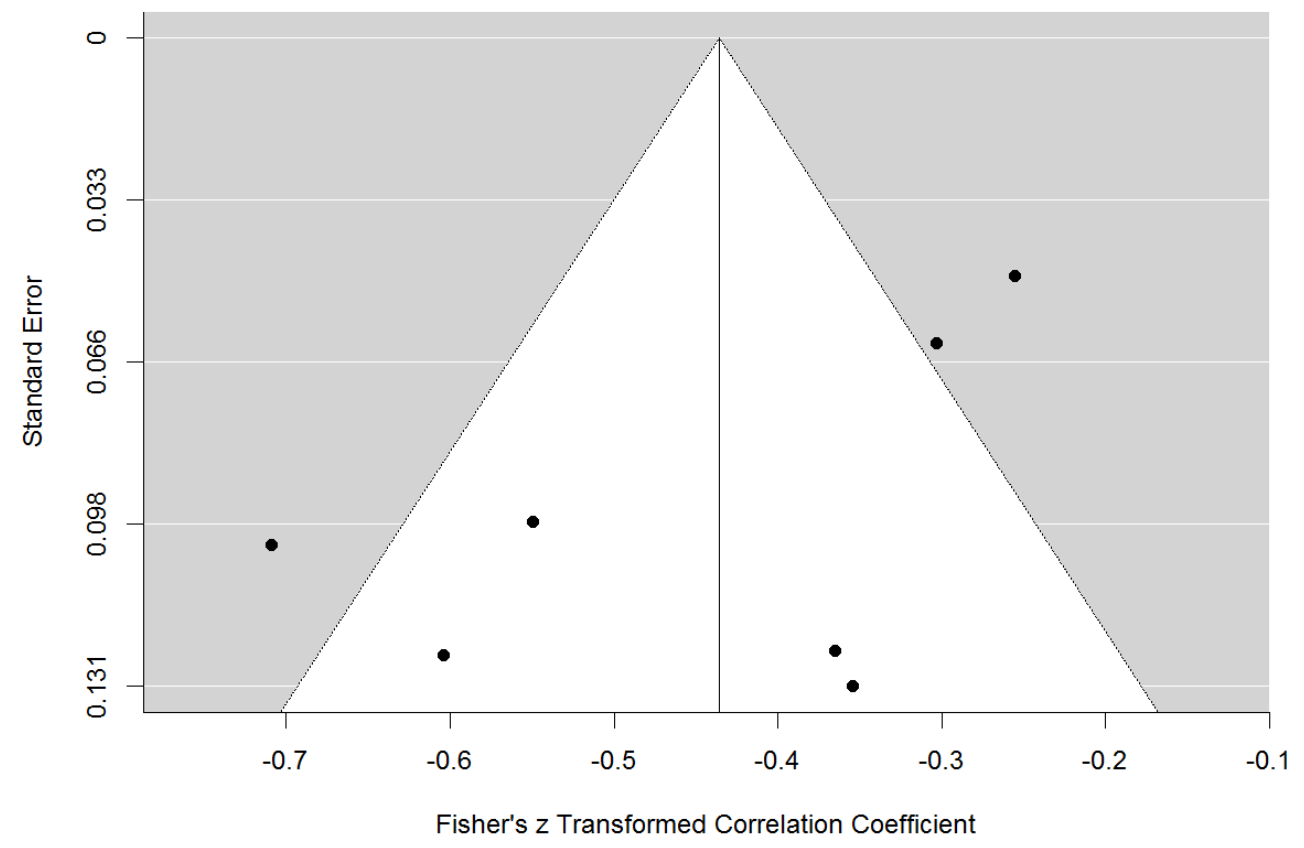

Figure 6. Funnel plot of Writing Academic Achievement. 
Journal for the Psychology of Language Learning, Volume 2, June 2020, Botes, Dewaele, \& Greiff supplementary materials. ISSN: 2642-7001. http://www.iapll.com/journal

\section{Listening Academic Achievement}

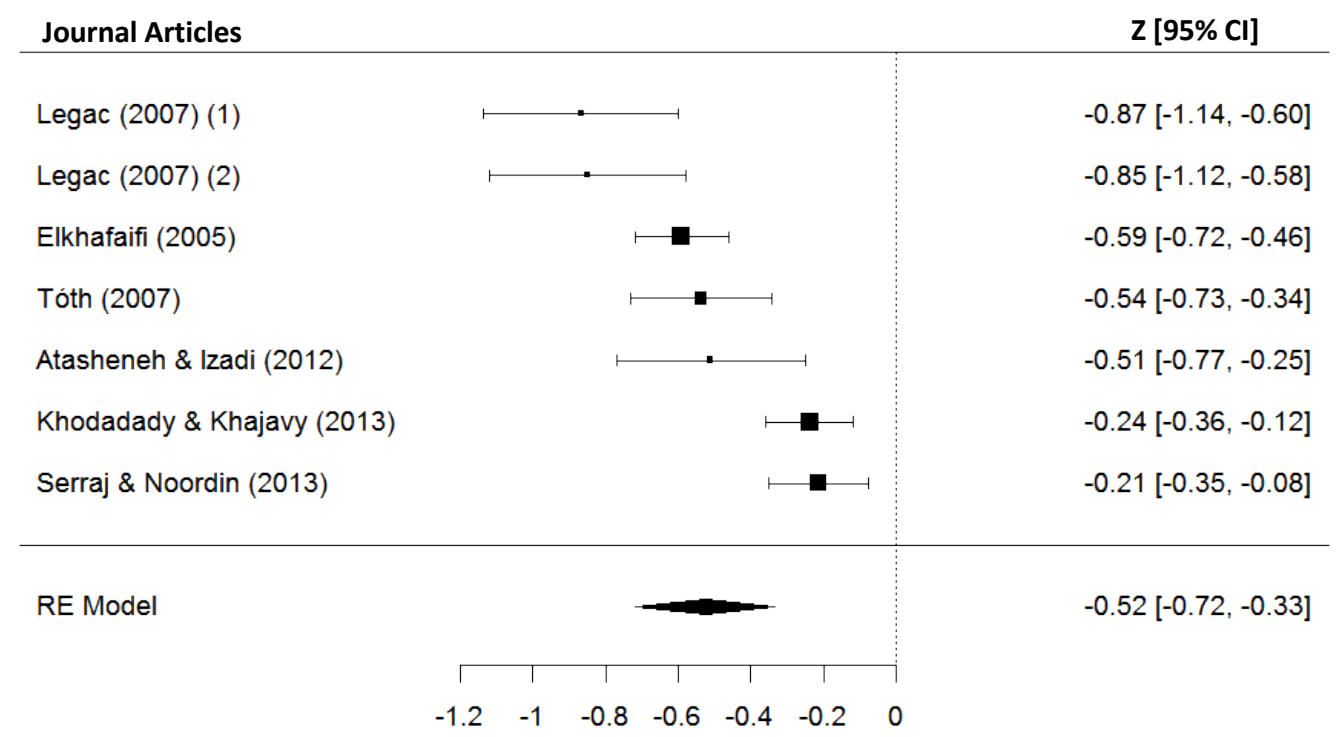

Figure 7. Fisher's Z transformed correlation coefficient forest plot of Writing Academic Achievement.

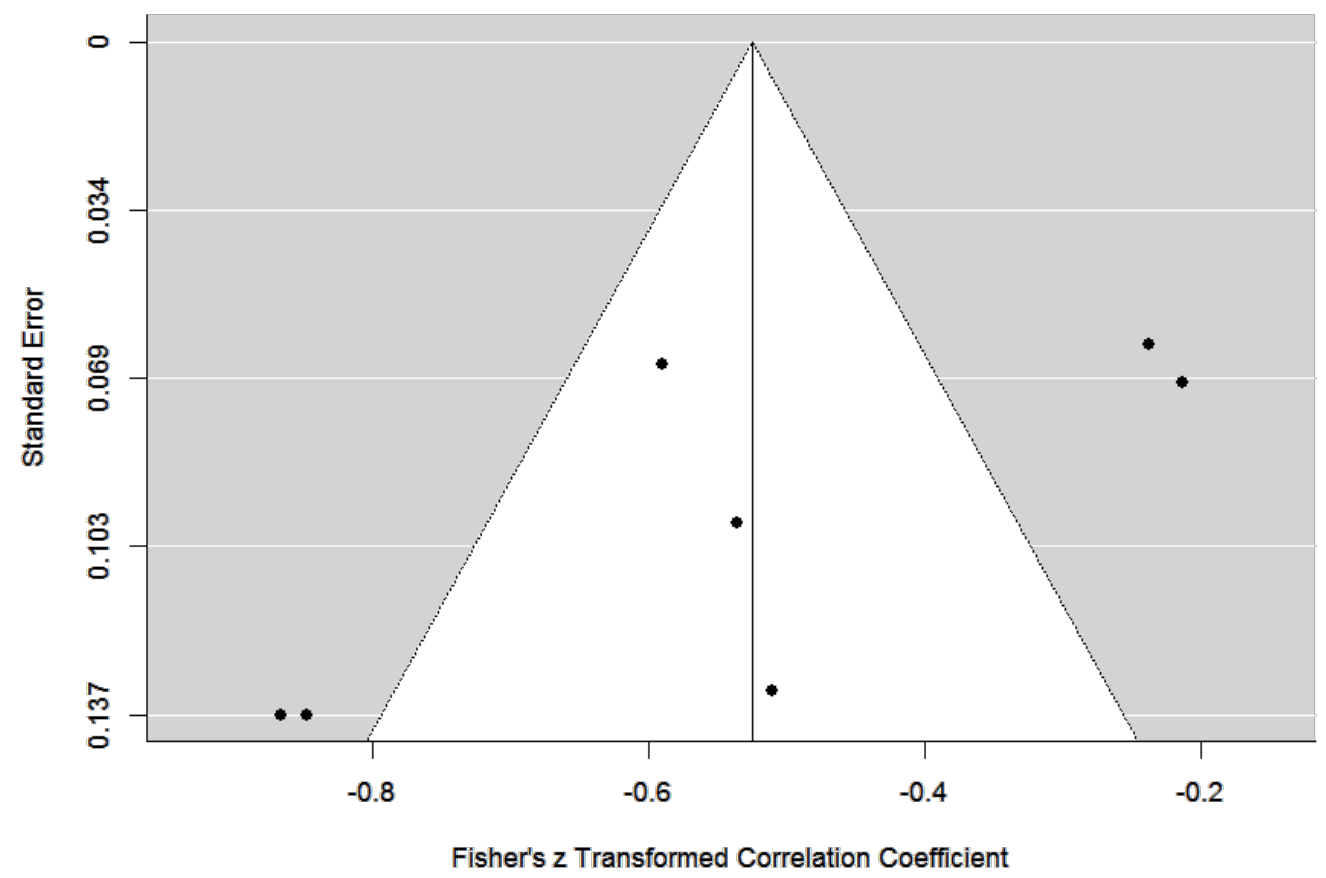

Figure 8. Funnel plot of Listening Academic Achievement. 
Journal for the Psychology of Language Learning, Volume 2, June 2020, Botes, Dewaele, \& Greiff supplementary materials. ISSN: 2642-7001. http://www.iapll.com/journal

\section{Speaking Academic Achievement}

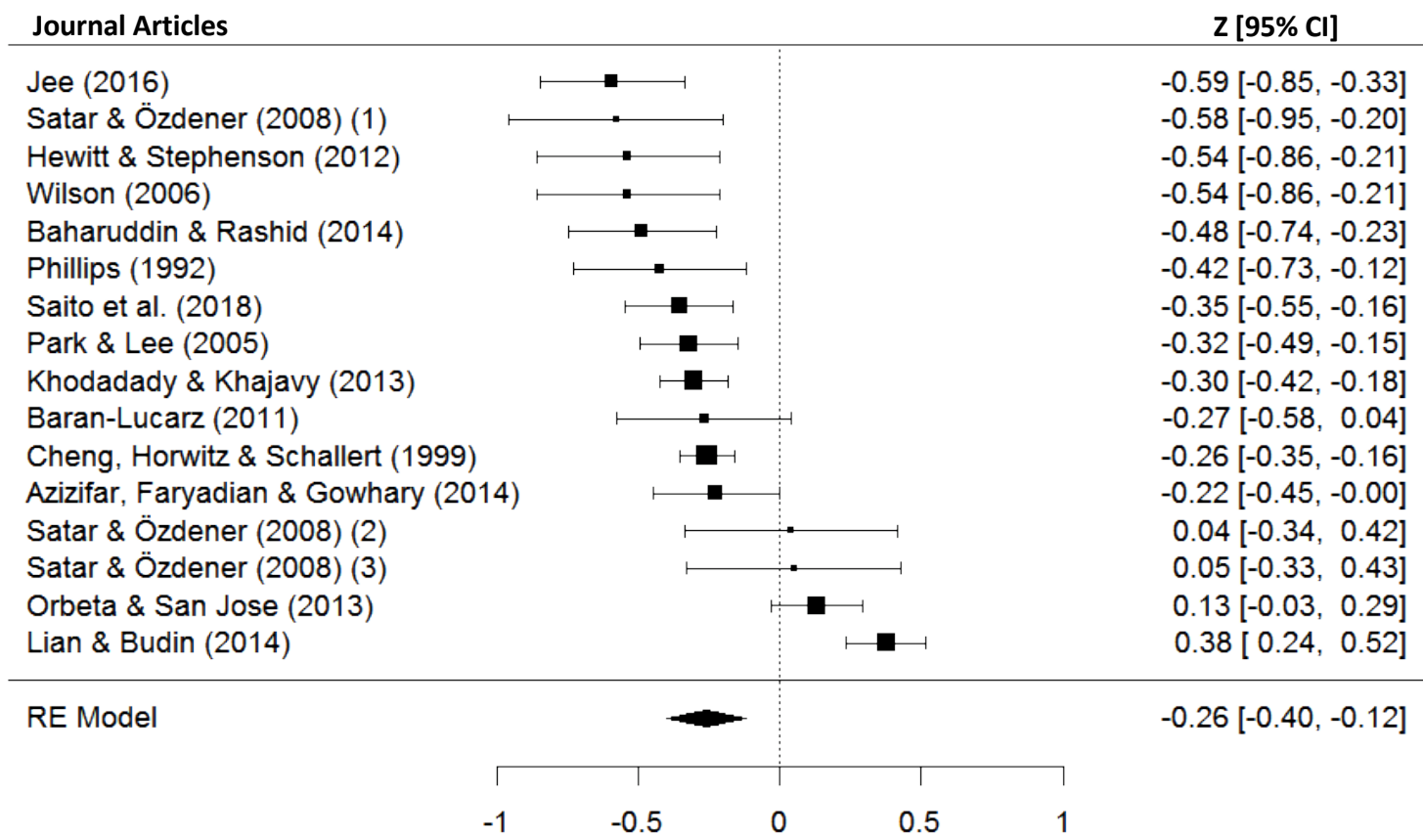

Figure 9. Fisher's Z transformed correlation coefficient forest plot of Writing Academic Achievement.

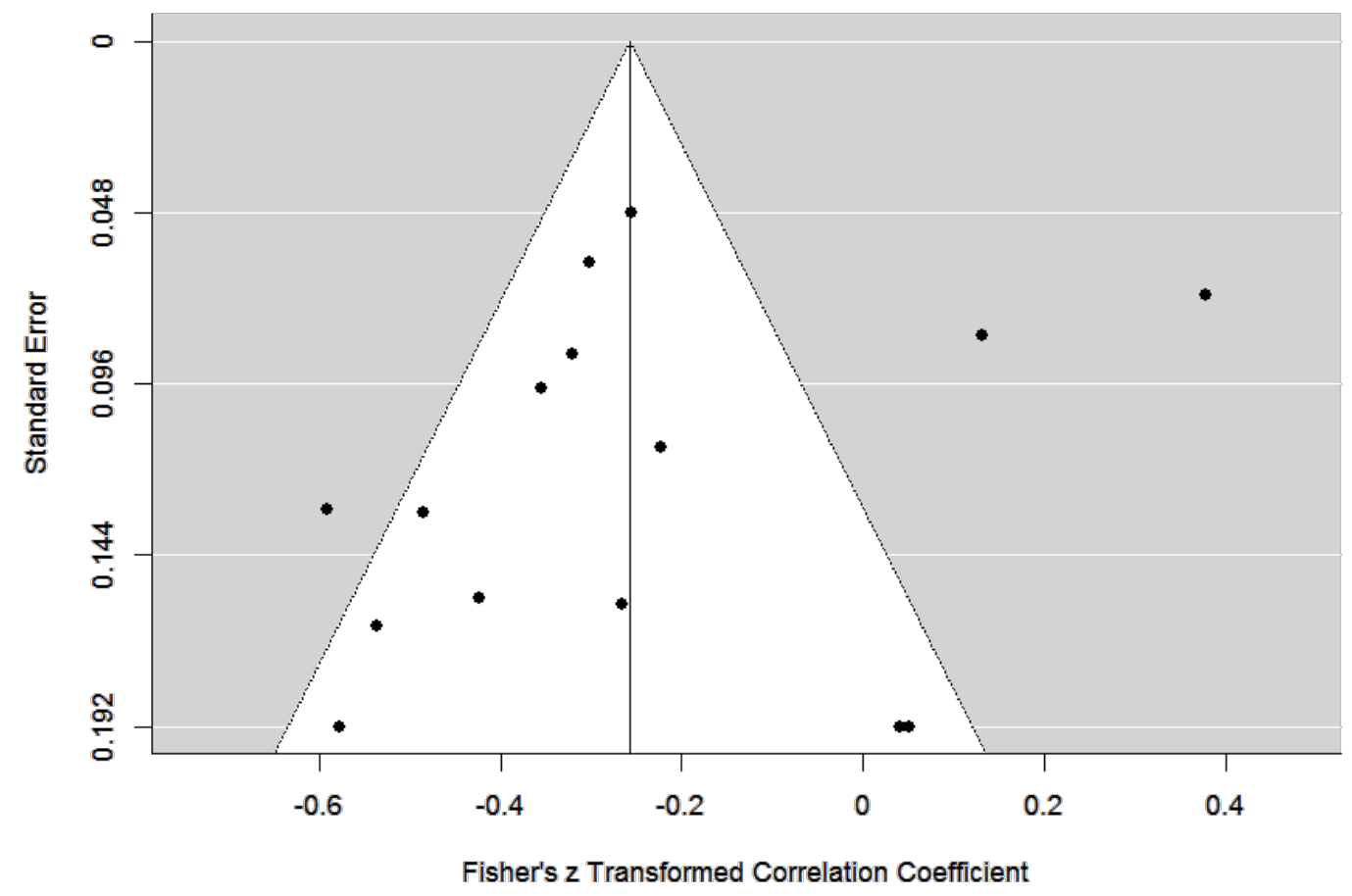

Figure 10. Funnel plot of Listening Academic Achievement. 
Journal for the Psychology of Language Learning, Volume 2, June 2020, Botes, Dewaele, \& Greiff supplementary materials. ISSN: 2642-7001. http://www.iapll.com/journal

\section{List of Articles Used in Meta-Analysis}

Abu-Rabia, S. (2004). Teachers' Role, Learners' Gender Differences, and FL Anxiety Among Seventh-Grade Students Studying English as a FL. Educational Psychology, 24(5), 711721. https://doi.org/10.1080/0144341042000263006

Aida, Y. (1994). Examination of Horwitz, Horwitz, and Cope's Construct of Foreign Language Anxiety: The Case of Students of Japanese. The Modern Language Journal, 78(2), 155168. https://doi.org/10.1111/j.1540-4781.1994.tb02026.x

Alidoost, Y., Mirchenari, N. A. N., \& Mehr, S. H. (2013). The Effects of Anxiety on Iranian EFL Learners' Performance on Final Achievement Test in English Classes of High Schools. International Journal of Language Learning and Applied Linguistics World, 4(3), 284292.

Alrabai, F., \& Moskovsky, C. (2016). The Relationship between Learners' Affective Variables and Second Language Achievement. Arab World English Journal, 7(2), 77-103.

Amiri, M., \& Ghonsooly, B. (2015). The Relationship between English Learning Anxiety and the Students' Achievement on Examinations. Journal of Language Teaching and Research, 6(4), 855-865. https://doi.org/10.17507/jltr.0604.20

Anyadubalu, C. C. (2010). Self-Efficacy, Anxiety, and Performance in the English Language among Middle-School Students in English Language Program in Satri Si Suriyothai School, Bangkok. International Journal of Educational and Pedagogical Sciences, 4(3), 6.

Argaman, O., \& Abu-Rabia, S. (2002). The Influence of Language Anxiety on English Reading and Writing Tasks Among Native Hebrew Speakers. Language, Culture and Curriculum, 15(2), 143-160. https://doi.org/10.1080/07908310208666640

Arnaiz, P., \& Guillén, F. (2012). Foreign Language Anxiety in a Spanish University Setting: Interpersonal Differences. Revista de Psicodidáctica, 17(1), 5-26.

Atasheneh, N., \& Izadi, A. (2012). The Role of Teachers in Reducing/Increasing Listening Comprehension Test Anxiety: A Case of Iranian EFL Learners. English Language Teaching, 5(3), 178-187.

Atef-Vahid, S., \& Kashani, A. F. (2011). The Effect of English Learning Anxiety on Iranian High-School Students' English Language Achievement. Broad Research in Artificial Intelligence and Neuroscience, 2(3), 29-44.

Awan, R.-N., Azher, M., Anwar, M. N., \& Naz, A. (2010). An Investigation Of Foreign Language Classroom Anxiety And Its Relationship With Students Achievement. Journal of College Teaching \& Learning, 7(11), 33-40. https://doi.org/10.19030/tlc.v7i11.249 
Azizifar, A., Faryadian, E., \& Gowhary, H. (2014). The Effect of Anxiety on Iranian EFL Learners' Speaking Skill. International Research Journal of Applied and Basic Sciences, $8(10), 1747-1754$.

Baharuddin, S. S., \& Rashid, S. M. D. (2014). English Language Learning Anxiety and Oral Performance among Undergraduate Learners. Journal of Language and Communication, $1(2), 137-153$.

Baran-Lucarz, M. (2011). The Relationship between Language Anxiety and the Actual and Perceived Levels of Foreign Language Pronunciation. Studies in Second Language Learning and Teaching, 1(4), 491-514.

Chakrabarti, A., \& Sengupta, M. (2012). Second Language Learning Anxiety and Its Effect on Achievement in the Language. Language in India, 12(8), 50-78.

Chan, D. Y., \& Wu, G. (2004). A Study of Foreign Language Anxiety of EFL Elementary School Students in Taipei County. Journal of National Taipei Teachers College, 17(2), $287-320$

Chen, I.-J., \& Chang, C.-C. (2009). Cognitive Load Theory: An Empirical Study of Anxiety and Task Performance in Language Learning. Electronic Journal of Research in Educational Psychology, 7(2), 729-746.

Cheng, Y., Horwitz, E. K., \& Schallert, D. L. (1999). Language Anxiety: Differentiating Writing and Speaking Components. Language Learning, 49(3), 417-446. https://doi.org/10.1111/0023-8333.00095

Chun, S., Kim, H., Park, C.-K., McDonald, K., Sun Ha, O., Kim, D. L., \& Lee, S. M. (2017). South Korean students' responses to English-medium instruction courses. Social Behavior and Personality: An International Journal, 45(6), 951-966. https://doi.org/10.2224/sbp.6049

Dewaele, J.-M., Özdemir, C., Durmus, K., Uysal, S., Özdemir, E. D., \& Balta, N. (Unpublished). The effect of classroom emotions, attitudes and sociobiographical variables on foreign language exam performance of high school and university learners. Unpublished Manuscript, 1-16.

Doğan, Y., \& Tuncer, M. (2016). Examination of Foreign Language Classroom Anxiety and Achievement in Foreign Language in Turkish University Students in Terms of Various Variables. Journal of Education and Training Studies, 4(5), 18-29. https://doi.org/10.11114/jets.v4i5.1337

Dordinejad, G. F., \& Ahmadabad, M. R. (2014). Examination of the Relationship between Foreign Language Classroom Anxiety and English Achievement among male and female Iranian High School students. International Journal of Language Learning and Applied Linguistics World, 6(4), 446-460. 
Elkhafaifi, H. (2005). Listening Comprehension and Anxiety in the Arabic Language Classroom. The Modern Language Journal, 89(2), 206-220. https://doi.org/10.1111/j.15404781.2005.00275.x

Ganschow, L., Sparks, R. L., Anderson, R., Javorshy, J., Skinner, S., \& Patton, J. (1994). Differences in Language Performance among High-, Average-, and Low-Anxious College Foreign Language Learners. The Modern Language Journal, 78(1), 41-55. https://doi.org/10.1111/j.1540-4781.1994.tb02013.x

Gardner, R. C., Tremblay, P. F., \& Masgoret, A.-M. (1997). Towards a Full Model of Second Language Learning: An Empirical Investigation. The Modern Language Journal, 81(3), 344-362. https://doi.org/10.1111/j.1540-4781.1997.tb05495.x

Ghorbandordinejad, F., \& Nasab, A. H. F. (2013). Examination of the relationship between perfectionism and English achievement as mediated by foreign language classroom anxiety. Asia Pacific Education Review, 14(4), 603-614. https://doi.org/10.1007/s12564013-9286-5

Gocer, A. (2014). The Relationship between Anxiety and Attitude of Students Learning Turkish as a Foreign Language and Their Achievement on Target Language. Educational Research and Reviews, 9(20), 879-884.

Hewitt, E., \& Stephenson, J. (2012). Foreign Language Anxiety and Oral Exam Performance: A Replication of Phillips's MLJ Study. The Modern Language Journal, 96(2), 170-189. https://doi.org/10.1111/j.1540-4781.2011.01174.x

Horwitz, E. K. (1986). Preliminary Evidence for the Reliability and Validity of a Foreign Language Anxiety Scale. TESOL Quarterly, 20(3), 559-562. https://doi.org/10.2307/3586302

Jee, M. J. (2014). Affective factors in Korean as a Foreign Language: Anxiety and beliefs. Language, Culture and Curriculum, 27(2), 182-195. https://doi.org/10.1080/07908318.2014.918626

Jee, M. J. (2016). Exploring Korean heritage language learners' anxiety: 'We are not afraid of Korean!' Journal of Multilingual and Multicultural Development, 37(1), 56-74. https://doi.org/10.1080/01434632.2015.1029933

Kamarulzaman, M. H., Ibrahim, N., Yunus, M. M., \& Ishak, N. M. (2013). Language Anxiety among Gifted Learners in Malaysia. English Language Teaching, 6(3), 20-29.

Khodadady, E., \& Khajavy, G. H. (2013). Exploring the Role of Anxiety and Motivation in Foreign Language Achievement: A Structural Equation Modeling Approach. Porta Linguarum, 20, 269-286. 
Legac, V. (2007). Foreign-Language Anxiety and Listening Skill in Croatian Monolingual and Bilingual Students of EFL. In J. Horváth \& M. Nikolov (Eds.), UPRT 2007: Empirical Studies in English Applied Linguistics (pp. 217-243). Lingua Franca Csoport.

Lian, L. H., \& Budin, M. (2014). Investigating the Relationship Between English Language Anxiety and the Achievement of School Based Oral English Test Among Malaysian Form Four Students. International Journal of Learning, Teaching and Educational Research, 2(1). Retrieved from http://ijlter.org/index.php/ijlter/article/view/32

Liu, H.-J. (2013). Effects of Foreign Language Anxiety and Perceived Competence on Learning Strategy Use. International Journal of English Linguistics, 3(3), 76-87. https://doi.org/10.5539/ijel.v3n3p76

Liu, M., \& Huang, W. (2011). An Exploration of Foreign Language Anxiety and English Learning Motivation. Education Research International, 2011, 1-8. https://doi.org/10.1155/2011/493167

Liu, M., \& Zhang, W. (2008). An exploration of Chinese EFL learners' foreign language anxiety, personality and self-esteem. Journal of Applied Linguistics, 5(2), 181-203.

Liu, M., \& Zhang, X. (2013). An Investigation of Chinese University Students 'Foreign Language Anxiety and English Learning Motivation. English Linguistics Research, 2(1), 1-13. https://doi.org/10.5430/elr.v2n1p1

Loo, D. B., \& Kitjaroonchai, N. (2015). Gender, Academic Achievement and Years of Experience: Investigating Potential Reasons for Foreign Language Anxiety among Thai High School Students. The New English Teacher, 9(2), 73-93.

MacIntyre, P. D. (1992). Anxiety And Language Learning From A Stages Of Processing Perspective ( $\mathrm{PhD}$, The University of Western Ontario). Retrieved from https://ir.lib.uwo.ca/digitizedtheses/2155/

Marcos-Llinás, M., \& Garau, M. J. (2009). Effects of Language Anxiety on Three ProficiencyLevel Courses of Spanish as a Foreign Language. Foreign Language Annals, 42(1), 94111. https://doi.org/10.1111/j.1944-9720.2009.01010.x

Matsumura, Y. (2001). An Inquiry into Foreign Language Reading Anxiety among Japanese EFL Learners. Eibeibunka: Studies in English Language, Literature and Culture, 31, 23 38. https://doi.org/10.20802/eibeibunka.31.0_23

Na, Z. (2007). A Study of High School Students' English Learning Anxiety. The Asian EFL Journal, 9(3), 22-34.

Olivares-Cuhat, G. (2010). Relative Importance of Learning Variables on L2 Performance. Linguistik Online, 43(3), 99-116. 
Onwuegbuzie, A. J., Bailey, P., \& Daley, C. E. (1999). Factors associated with foreign language anxiety. Applied Psycholinguistics, 20(2), 217-239.

https://doi.org/10.1017/S0142716499002039

Onwuegbuzie, A. J., Bailey, P., \& Daley, C. E. (2000). Cognitive, Affective, Personality, and Demographic Predictors of Foreign-Language Achievement. The Journal of Educational Research, 94(1), 3-15. https://doi.org/10.1080/00220670009598738

Orbeta, E. D., \& San Jose, A. E. (2013). Apprehension in Language Learning Anxiety as Significant Correlate of Oral Performance in English of College Freshmen. International Journal of Multidisciplinary Research, 5(1). https://doi.org/10.7718/iamure.v5i1.622

Park, H., \& Lee, A. (2006). L 2 Learners' Anxiety, Self-Confidence and Oral Performance. Proceedings of the 10th Conference of Pan-Pacific Association of Applied Linguistics, 197-208. Retrieved from http://www.paaljapan.org/resources/proceedings/PAAL10/pdfs/hyesook.pdf

Phillips, E. M. (1992). The Effects of Language Anxiety on Students' Oral Test Performance and Attitudes. The Modern Language Journal, 76(1), 14-26. https://doi.org/10.1111/j.15404781.1992.tb02573.x

Rastegar, M., \& Karami, M. (2015). On the Relationship between Foreign Language Classroom Anxiety, Willingness to Communicate and Scholastic Success among Iranian EFL Learners. Theory and Practice in Language Studies, 5(11), 2387-2394. https://doi.org/10.17507/tpls.0511.25

Salehi, M., \& Marefat, F. (2014). The Effects of Foreign Language Anxiety and Test Anxiety on Foreign Language Test Performance. Theory and Practice in Language Studies, 4(5). https://doi.org/10.4304/tpls.4.5.931-940

Satar, H. M., \& Özdener, N. (2008). The Effects of Synchronous CMC on Speaking Proficiency and Anxiety: Text Versus Voice Chat. The Modern Language Journal, 92(4), 595-613. https://doi.org/10.1111/j.1540-4781.2008.00789.x

Serraj, S., \& Noordin, N. B. (2013). Relationship among Iranian EFL Students’ Foreign Language Anxiety, Foreign Language Listening Anxiety and Their Listening Comprehension. English Language Teaching, 6(5), 1-12.

Shao, K., Yu, W., \& Ji, Z. (2013). An exploration of Chinese EFL students' emotional intelligence and foreign language anxiety. The Modern Language Journal, 97(4), 917929. https://doi.org/10.1111/j.1540-4781.2013.12042.x

Shinge, M. (2005). Interplay among Anxiety, Motivation, and Autonomy in Second Language Learners of French: A Quantitative and Qualitative Study (PhD, University of Florida). Retrieved from http://etd.fcla.edu/UF/UFE0011620/shinge_m.pdf 
Journal for the Psychology of Language Learning, Volume 2, June 2020, Botes, Dewaele, \& Greiff supplementary materials. ISSN: 2642-7001. http://www.iapll.com/journal

Sparks, R. L., \& Ganschow, L. (2007). Is the Foreign Language Classroom Anxiety Scale Measuring Anxiety or Language Skills? Foreign Language Annals, 40(2), 260-287. https://doi.org/10.1111/j.1944-9720.2007.tb03201.x

Subekti, A. S. (2018). Investigating the Relationship between Foreign Language Anxiety and Oral Performance of Non-English Major University Students in Indonesia. Dinamika Ilmu, 18(1), 15-35.

Tanielian, A. R. (2014). Foreign Language Anxiety in a New English Program in Thailand. International Education Journal: Comparative Perspectives, 13(1), 60-81.

Tanielian, A. R. (2017). Foreign language anxiety among first-year Saudi university students. The International Education Journal: Comparative Perspectives, 16(2), 116-130.

Tittle, M. (1997). The Effects of Foreign and Second Language Students' Irrational Beliefs and Anxiety on Classroom Achievement (PhD, University of Illinois). Retrieved from https://eric.ed.gov/?id=ED411674

Tóth, Z. (2007). Predictors of Foreign-Language Anxiety: Examining the Relationship Between Anxiety and Other Individual Learner Variables. In J. Horváth \& M. Nikolov (Eds.), UPRT 2007: Empirical studies in English applied linguistics, 123-148. Retrieved from http://vmek.niif.hu/07500/07557/07557.pdf\#page=129

Vo, T. D., Samoilova, V., \& Wilang, J. D. (2017). Debilitating Effects of Anxiety on Engineering Students' Language Performances. 275-285. Retrieved from https://eric.ed.gov/?id=ED583662

von Worde, R. (1998). An Investigation of Students' Perspectives on Foreign Language Anxiety ( $\mathrm{PhD}$, George Mason University). Retrieved from https://eric.ed.gov/?id=ED479986

Wang, Y., \& Li, J. (2011). The interference of foreign language anxiety in the reading comprehension of agricultural engineering students. 2011 International Conference on New Technology of Agricultural, 660-663. https://doi.org/10.1109/ICAE.2011.5943882

Wilson, Jean. T. S. (2006). Anxiety in Learning English as a Foreign Language: Its Associations with Student Variables, with Overall Proficiency, and with Performance on an Oral Test ( $\mathrm{PhD}$, University of Grenada). Retrieved from http://digibug.ugr.es/bitstream/handle/10481/1074/162?sequence=1

Zhao, A., \& Whitchurch, A. (2011). Anxiety and its Associated Factors in College-Level Chinese Classrooms in the U.S. Journal of the Chinese Language Teachers Association, $46(3), 21-47$. 